\title{
Due Diligence and un Support for African Union Security Forces
}

\section{Peacekeeper Sexual Violence Exploitation and Abuse}

\author{
Róisín Burke \\ Senior Lecturer, School of Law, University of Canterbury \\ roisin.burke@canterbury.ac.nz
}

\begin{abstract}
Complicity by UN military peacekeepers in sexual abuse and sexual exploitation ('SEA') has been in the lime light in academic, practice and policy circles for many years now. Recent scandals involving sexual violence and abuse by peacekeepers in the Central African Republic and failures to respond are proving the catalyst for major reforms being discussed and implemented currently at UN level. There are numerous legal complexities, difficulties and flaws with the legal framework, policies and systems presently in place. Less considered are the parallel regulatory frameworks operative, or not operative, in the context of peacekeeping done beyond the remit of the United Nations or by those not deployed under its command and control. The fact remains that SEA is also prevalent across these peace operations but very little focus has been placed on these by academics or practitioners alike. Increasingly the UN is likely to rely on regional bodies in conducting peace operations falling outside its SEA regulatory framework. This may leave local populations vulnerable to unregulated or poorly regulated acts of sexual abuse and exploitation by peacekeepers. This paper seeks to address a gap in the literature in examining this regulatory space, focusing on the African Union's ('AU's') policy and regulatory frameworks governing its personnel deployed to peace operation environments in so far as they appear to exist. In doing so, it will reflect on the relationship this has to the Un's Human Rights Due Diligence Policy on United Nations Support to Non-United Nations Security Forces, and the increasing reliance on AU regional peace operations, and re-hatting of forces.
\end{abstract}

\section{Keywords}

African Union - sexual abuse and exploitation - regulation - peace operations United Nations Due Diligence Policy - re-hatting 


\section{Introduction}

Complicity by UN military peacekeepers in criminal offences and human rights violations, most visibly sexual abuse and sexual exploitation ('SEA') has been well documented in academic, practice and policy circles for many years now. The presence of peacekeepers often coincides with a rise in prostitution or survival sex, but also fundamentally rape, abuse of minors and other forms of sexual violence by a minority of peacekeeping personnel. ${ }^{1}$ What is less highlighted is that this conduct by UN peacekeepers is only one aspect of broader issues with respect to criminal offences and human rights violations by multinational deployments of peacekeepers. ${ }^{2}$ In particular, little research has been conducted on the regulation of regional peace operations such as those conducted by the African Union ('AU'). The pertinence of such research is evident in light of the likelihood of increased reliance on non-UN, regional security forces in the maintenance of international and regional peace and security. SEA is also a singular aspect of the problem, but will be focused on here, in the context of the $\mathrm{AU}$, as an example of gaps in the regulatory frameworks governing regional peacekeeping operations with respect to ensuring adherence to international humanitarian law ('IHL'), international human right law ('IHRL') and criminal offences more broadly. A case, in example, were serious allegations of sexual abuse, violence, and exploitation occurring at

1 See further, Róisín Burke, Sexual Exploitation and Abuse by uN Military Contingents: Moving Beyond the Status Quo and Responsibility under International Law (Leiden: Brill Martinus Nijhoff, 2014), Chapter 1 ('Sexual Exploitation and Abuse: Moving Beyond'); A Comprehensive Strategy to Eliminate Future Sexual Exploitation and Abuse in the United Nations Peacekeeping Operations, $59^{\text {th }}$ sess, Agenda Item 77, UN Doc A/59/710 (24 March 2005) [6] ('Zeid's Report'); Olivera Simic, 'Accountability of Un Civilian Police Involved in Trafficking of Women in Bosnia and Herzegovina', University for Peace and Conflict Monitor (online), 16 November 2004 $<$ http://www.monitor.upeace.org/innerpg.cfm?id_article=219>; Sarah Martin, 'Must Boys Be Boys? Ending Sexual Exploitation \& Abuse in UN Peacekeeping', Refugees International, October 2005, p. 5 <http://www.pseataskforce.org/uploads/tools/mustboysbeboysendingseainunpeacekeepingmissions_refugeesinternational_english.pdf>; Gabrielle Simm, Sex in Peace Operations (Cambridge: Cambridge University Press, 2013); Ai Kihara-Hunt, Holding UNPOL to Account: Individual Criminal Accountability of United Nations Police Personnel (Leiden: Brill, Martinus Nijhoff, 2017).

2 See e.g., Marie Deschamps, Hassan B. Jallow and Yasmin Sooka, Taking Action on Sexual Abuse and Exploitation by Peacekeepers: Report of an Independent Review on Sexual Exploitation and Abuse by International Peacekeeping Forces in the Central African Republic (17 December 2015) p. 34 ('CAR Panel Report'); Yan McCarrel, 'The United Nations and Sexual Abuse: Why Peacekeeping Reform has Failed', Foreign Affairs (online ed, New York, 14 February 2016). 
the hands of non-UN security forces in the Central African Republic ('CAR') in 2015 .

Several reports have been pivotal in highlighting both the extent of SEA by peacekeepers, within and outside the UN, and an array of institutional problems, some of which we will address in this paper. These include, for instance, AIDs Free World's Code Blue campaign's leaking a number of confidential reports over the past couple of years; the leaking by a former employee of UN Office of the High Commission for Human Rights ('OHCHR') of a confidential UN Children's Fund ('UNICEF') report in May 2015, revealing widespread child sex abuse by non-UN security forces in CAR; and a 2014 Human Rights Watch Report alleging SEA by African Union Mission in Somalia ('AMISOM') personnel deployed to Somalia. The UNICEF Report led to an inquiry and substantial report by an independent Group of Experts, released in December 2015. The report documents serious UN institutional failures in dealing with allegations of SEA. The report also highlighted an oft- overlooked problem, namely the regulation of crimes or human rights violations (here sexual offences) by nonUN security forces, including regional peacekeepers. A substantial proportion of the CAR allegations involved sexual violence, abuse of children, and even an allegation of bestiality involving four young girls. Implicated, non-UN, troops included the French Sangaris forces, troops from Chad and Equatorial Guinea deployed under the AU-led International Support Mission in the Central African Republic ('MISCA'). ${ }^{3}$ During 2016, alone, there were at least 311 know victims of SEA by UN peacekeepers recorded in official UN statistics. According the UN Secretary-General ('sG'), '[n] on-United Nations international forces operating under Security Council mandates accounted for 20 allegations, involving an additional 20 victims' in $2016 .{ }^{4}$ There are many other accounts of SEA by peacekeepers being reported by NGOs and others, therefore, it is unlikely this number is representative of the reality. As highlighted by the UN SG lack of protections afforded to SEA victims and witnesses in the context of non-UN security forces, undermines reporting of such abuse and ability to follow-up allegations. Moreover, there is no one clear reporting mechanism across peace

3 CAR Panel Report, above n 2, ii; See further, Róisín Sarah Burke, 'Central African Republic Peacekeeper Sexual Crimes, Institutional Failings: Addressing the Accountability Gap', 14 New Zealand Journal of Public International Law (2016) 97.

4 Special Measures for Protection from Sexual Exploitation and Abuse: A New Approach Report of the Secretary-General, UN Doc A/71/818 (28 February 2017) [8]. 
operations. As highlighted by the SG, 'therefore, the data presented in the present report are not to be read as a comprehensive reflection of the actual scale of the problem. 5 The majority of the 20 allegations that were reported involved sexual abuse of children in Internally Displaced Persons ('IDP') camps; namely eleven girls and four boys. Twelve were allegedly raped. ${ }^{6}$ Reports of abuses by MISCA troops were not limited to SEA, but also other human rights abuses. ${ }^{7}$ During 2015 alone, there were over 100 reported incidents of SEA by both military and civilian peacekeepers deployed to CAR. ${ }^{8}$

While the focus of this paper is on sexual violence, abuse and exploitation, ${ }^{9}$ these incidents are clearly demonstrative of the broader problem of regulation of crime by peacekeepers, deployed often to situations where the rule of law is weak or absent, and in any respect where they are likely immune from the host state's criminal justice system. There have been no charges by the French courts with respect to the sexual abuse allegations against the French Sangaris forces, despite an investigation. ${ }^{10}$ There is also little information available on

$5 \quad$ Ibid., [32], [34].

6 Ibid., [34]-[35].

7 See, Human Rights Watch, Central African Republic: Murder by Peacekeepers - Discovery of Mass Grave Provides New Evidence (2016) <https://www.hrw.org/news/2016/06/07/ central-african-republic-murder-peacekeepers $>$.

8 Ryan McCarrel, 'The United Nations and Sexual Abuse: Why Peacekeeping Reform has Failed', Foreign Affairs (online), 14 February $2016<$ https://www.foreignaffairs.com/arti cles/2016-02-14/united-nations-and-sexual abuse>; Margaux Benn, 'un Sex Scandal in the Central African Republic Hits Rock Bottom', Foreign Affairs (online) 18 April 2016 <http:// foreignpolicy.com/2016/04/o8/u-n-sex-abuse-scandal-in-central-african-republic-hits -rock-bottom/>; For a breakdown of statistics on SEA by UN peacekeepers only, see, the un Conduct and Discipline Unit website, however, the data does not match up. See UN Conduct and Discipline Unit Website <https://cdu.unlb.org/Statistics/Allegationsby CategoryofPersonnelSexualExploitationandAbuse/AllegationsforAllCategoriesofPerson nelPerYearSexualExploitationandAbuse.aspx>.

9 United Nations, United Nations Glossary on Sexual Exploitation and Abuse Thematic Glossary of current terminology related to Sexual Exploitation and Abuse (SEA) in the context of the United Nations; Special Coordinator on improving the United Nations response to sexual exploitation and abuse ( $\left.2^{\text {nd }} \mathrm{ed}, 2017\right)<$ https://hr.un.org/sites/hr.un.org/files/SEA\%20 Glossary\%20\%20\%5BSecond\%2oEdition\%20-\%202017\%5D\%20-\%2oEnglish_o.pdf> ('UN Glossary of Terms').

10 BenoÎt Morenne, 'No Charges in Sexual Abuse Case Involving French Peacekeepers', New York Times (online), 6 January 2017 <https:/www.nytimes.com/2017/o1/o6/world/africa/ french-peacekeepers-un-sexual-abuse-case-central-african-republic.html $>$. 
what, if anything has occurred with respect to allegations against other peacekeepers implicated.

The subsequent re-hatting of a significant portion of the AU's MISCA troops to the United Nations Multidimensional Integrated Stabilization Mission in the Central African Republic ('MINUSCA') in 2014, ${ }^{11}$ gives rise to a number of further legal and policy considerations in terms of criminal and disciplinary frameworks. Transition from an AU operation to a UN operation was envisaged in the early planning phases of the MISCA operation. ${ }^{12}$ There have also been moves more broadly by the UN to support deployments by regional organizations to peace operations. In this paper particular focus is placed on building on the AU's peace and security architecture, but the UN has also worked in partnership with the EU, NATO, etc. In doing so, possible broader issues of complicity and international organisation responsibility arise. ${ }^{13}$ As will be discussed presently, this calls for consideration of the Un's Human Rights Due Diligence Policy ('HRDDP').

The author began this research with a view exploring the regulatory frameworks for SEA arising in the context of peace operations conducted by regional organizations. However, in light of the complex relationships arising from the increased prevalence of regional bodies, in particular the AU, conducting peace operations a shift in focus to the HRDDP appears necessary. Moreover, there is a dearth in information, at least publically accessible, on the internal workings of the $\mathrm{AU}$ from a regulatory perspective and its relationship with its

11 United Nations Peacekeeping, MINUSCA <http://www.un.org/en/peacekeeping/missions/ minusca/>; See further, Tatiana Carayannis and Mignonne Fowlis, 'AU and UN Cooperation in Peace Operations in the Central African Republic', African Politics, African Peace Project, Program on African Peace Missions, Paper. 13 (June 2016) <http://fletcher .tufts.edu/ /media/Fletcher/Microsites/World\%2oPeace\%2oFoundation/African\%2o Peace\%2oMissions/Research/13\%20AU\%20and\%2oUN\%2oCAR\%2oCarayannis\%2o and\%2oFowlis.pdf $>$.

12 Letter dated 11 March 2014 from the Secretary-General addressed to the President of the Security Council, un Doc s/2014/172 (12 March 2014), 21-22, [76]-[80]; Information Note on the Report of the UN Secretary-General on the Central African Republic Pursuant to Paragraph 48 of Security Council Resolution 2127 (2013), AU Doc PSC/PR/2.(CDXXII) (7 March 2014).

13 See, Burke, Sexual Exploitation and Abuse: Moving Beyond, above n 1, Chapters 6 and 3; Laurence Boisson de Chazournes, Interactions between Regional and Universal Organizations: A Legal Perspective (Leiden: Brill Martinus Nijhoff, 2016) pp. 142-254; Tom Dannenbaum, 'Translating the Standard of Effective Control into a System of Effective Accountability: How Should Liability be Apportioned for Violations of Human Rights' (2010) 51 Harvard International Law Journal, p. 113. 
troop and police contributing states. ${ }^{14}$ The UN's HRDDP gives rise to implications for vetting prior to deployment and monitoring with respect to violations of IHL and IHRL by non-UN security forces supported by the UN. ${ }^{15}$ The HRDDP requires the UN to monitor adherence to IHL, IHRL, and refugee law when lending support. The HRDDP may offer processes by which to ensure at least better regulation over criminal conduct violating these standards by peacekeeping personnel deploying outside the Un's remit, but which it, nevertheless, supports. The HRDDP should be amended to specifically incorporate SEA. It is of course necessary for organizations such as the AU to adopt their own proper regulatory processes and standards more broadly to adequately govern their personnel and ensure their own adherence to, and reputations for compliance with, international law.

The AU has deployed a number of recent and present peace operations, including AM ISOM in Somalia; the African Union-United Nations Mission in Darfur; and the Regional Cooperation Initiative for the Elimination of the LRA. Recently concluded operations, include the AU led International Support Mission in Mali ('AFISMA'); 16 MISCA until 2014 in CAR; AU Mission in Sudan; the $\mathrm{AU}$ mission to Comoros; and the AU mission in Burundi. ${ }^{17}$ Currently the $\mathrm{AU}$ has 22,126 uniformed personnel deployed to Ам Isом alone, which includes personnel from Burundi, Cameroon, Djibouti, Ethiopia, Gambia, Ghana, Kenya, Niger, Nigeria, Senegal, Sierra Leone, Uganda and Zambia. The largest troop-contributors are Uganda, Burundi, Djibouti, Kenya, Ethiopia and Sierra Leone. ${ }^{18}$ At the outset, it must be emphasized that AU peacekeepers have done tremendous work in relation to the protection of civilians and enhancing regional stability in Africa. Many have put their lives at risk, often deploying to highly volatile conflict environments where even the UN has proven unwilling

14 The author had no responses to multiple emails, with requests for information, sent to AU HQ, or AMISOM. This leaves one to wonder how victim communities obtain such information on processes for complaints and follow-up.

15 Identical Letters dated 25 February 2013 from the Secretary-General addressed to the President of the General Assembly and to the President of the Security Council, UN GAOR, UN SCOR, $67^{\text {th }}$ sess, UN Doc A/67/775-S/2013/110 (5 March 2013) Annex, Human Rights Due Diligence Policy on United Nations Support to Non-United Nations Security Forces ('HRDDP').

16 Boisson de Chazournes, above n 13, pp. 142-254.

17 Brief details on these operations can be found at: African Union <https://www.au.int/ web/en/organs/psc $>$.

18 AMISOM <http://amisom-au.org/frequently-asked-questions/>. 
or slow to deploy, sometimes given the need for more robust deployments. ${ }^{19}$ That stated, human rights and IHL violations, and criminal or disciplinary offences do happen and must be properly regulated, in particular in light of the likely proliferation of regional deployments. The $\mathrm{AU}$ is merely a case in example.

It also ought to be noted that the AU's peace and security architecture is still relatively nascent, with the Peace and Security Council ('PSC') established in 2002. ${ }^{20}$ Therefore, its regulatory structures are still under development. Article $5^{2}$ of the UN Charter provides that the Charter does not 'preclude the existence of regional arrangements of agencies for dealing with such matters relating to the maintenance of international peace and security as are appropriate for regional action, provided that such arrangements or agencies and their activities are consistent with the Purposes and Principles of the United Nations'. The AU's PSC was created by Protocol. It includes an African Standby Force, intended to enable rapid deployment in the maintenance of regional peace and security. ${ }^{21}$ This, in addition to the development of the African Peace and Security Architecture ('APSA') render the AU a significant actor in the maintenance of international peace and security. ${ }^{22}$ The APSA consists of four pillars collectively, including the PSC, the Panel of the Wise, the African Standby Force, the Continental Early Warning System, and the AU Peace Fund. ${ }^{23}$

Section I of this paper will provide a snapshot of allegations, in particular of SEA, as an example of criminal conduct or rights violations by AU peacekeepers, primarily troops, and contexts in which these have arisen. Focus will

19 See, e.g., Letter dated 21 July 2015 from the Secretary-General addressed to the President of the Security Council, un Doc S/2015/556 (21 July 2015); Report of the Secretary-General on Somalia, UN Doc s/2013/69 (31 January 2013).

20 Hussaina J. Abdullah, 'Women and the African Peace and Security Architecture', (African Peacebuilding Network APN Working Papers No. 10, Social Science Research Council, May 2017) p. 6 <https://s3.amazonaws.com/ssrc-cdn1/crmuploads/new_publication_3/\%7B78 FCD2E7-5F2F-E711-80C4-005056ABoBD9\%7 D.pdf>; Abou Jeng, 'Philosophy and structures of the African Union', in Peacebuilding in the African Union: Law, Philosophy and Practice (Cambridge: Cambridge University Press, 2012) pp. 163-201.

21 The Protocol, adopted 2 March 2001, entered into force on 14 December 2003. Protocol Relating to the Establishment of the Peace and Security Council of the African Union <http:// www.peaceau.org/uploads/psc-protocol-en.pdf $>$.

AU Doc PSC/PR/2(DII) (29 April 2015) p. $3<$ http://www.un.org/en/africa/osaa/pdf/au/cap _peaceops_2015.pdf $>$; Hikaru Yamashita, 'Peacekeeping cooperation between the United Nations and regional organisations' (2012) 38 Review of International Studies, p. 165.

Abdullah, above n 20, p. 6. 
be placed on allegations arising in the context of peacekeeping in CAR and Somalia.

Section II addresses, in brief, the relevance of I HL and I HRL. It then shifts focus to the AU Regulatory/Policy Framework. To some extent reliance is placed on a HRW report released in 2014 documenting serious allegations of SEA by AU peacekeepers deployed to the AMISOM operation and AU correspondence responding to the accusations. The report and subsequent AU response documents are amongst the few accessible information sources on the AU's regulatory and policy framework to address SEA, and are therefore central to the discussion in this paper. ${ }^{24}$ This, and the lack information that can be obtained elsewhere, leads one to suspect that subsequent developments have been minimal. Therefore, in all respects, this is a pivotal moment for the development of best, or at least better, practice with respect to SEA at AU level.

Section III will turn to a more detailed consideration of the UN'S HRDDP and its possible relevance to abuses by AU troops, re-hatting processes, monitoring, screening and more broadly SEA. In doing so, Section III will discuss possible synergies with recent developments within the UN attempting to better regulate SEA and prevent impunity for such. The author will explore how the AU might partner with the UN and/or adopt similar measures in developing better regulatory practice with respect to SEA by peacekeepers. In conclusion a number of recommendations will be made.

\section{African Union, SEA and Other Serious Criminal Offences or Human Rights Violations}

\section{Central African Republic}

As a starting point, it is useful to put the above-mentioned SEA abuse scandal in CAR into context. AU MISCA transited from the prior ECCAS Peace Consolidation Mission in the Central African Republic (MICOPAX) in December 2013 as a result of renewed crisis in the country. ${ }^{25}$ MICOPAX had been in CAR since 2008. MISCA was deployed with significant support from the UN and EU, including

\footnotetext{
24 While numerous attempts were made by the author to gather information from the AU on regulatory developments post these documents, they have not been forthcoming with this information.

25 Transfer of Authority from MICOPAX to MISCA, African Union Peace and Security (2013) $<$ http://www.peaceau.org/en/article/transfer-of-authority-from-micopax-to-misca $>$.
} 
financing of operations. ${ }^{26}$ MISCA was backed by the French Operation Sangaris, pursuant to UN SC Resolution $2127 .{ }^{27}$ BINUCA (the UN Integrated Peacebuilding Office in the Central African Republic, a political mission to CAR at the time), MISCA and other authorized non-UN security forces had a mandate to protect civilians (including the European Union Force in CAR), support DDR and SSR, restore stability, and enable humanitarian actors to deliver humanitarian assistance. The SC called on MISCA to carry out its mandate with full respect for IHL, IHRL and refugee law. The UN in turn was providing MISCA with technical and expert advice. ${ }^{28}$

MISCA transitioned into a UN multi-dimensional peace support operation on 15 September 2014, wherein a significant number of MISCA troops and police were re-hatted to MINUSCA via SC Res $2149 .{ }^{29}$ The UN SG stipulated that the 'MISCA troops and police will be the backbone of MINUSCA' ${ }^{30}$ BINUCA was also subsumed into MINUSCA. The transition took approximately 5 months from April 2014. ${ }^{31}$ SC Res 2149 authorized the deployment of a force of 12,000 peacekeepers. MINUSCA was to continue to operate in parallel with the support offered by the EU and French, non-UN security forces. ${ }^{32}$ SC Resolution 2217 emphasized the need for swift deployment, ${ }^{33}$ pertinent to saving lives on the ground. The urgency of the re-hatting process, amongst other factors, it appears led to inadequate screening of troops and systematic vetting, and the deployment of troops without adequate training, ${ }^{34}$ including with respect to gender, SEA and UN standards of conduct. That stated, the UN did deploy a team to provide some training on the protection of civilians. ${ }^{35}$ One might note,

\footnotetext{
26 SC Res 2127, UN SCOR, $7072^{\text {nd }}$ mtg, Un Doc S/RES/2127 (5 December 2013).

27 Ibid.

28 Ibid.

29 SC Res 2149, UnSCOR, $7153^{\text {rd }} \mathrm{mtg}$, S/RES/2149 (10 April 2014).

30 Report of the Secretary-General on the situation in the Central African Republic (1 August 2014) Security Council Report [71] <http://www.securitycouncilreport.org/atf/cf/\%7B65 BFCF9B-6D27-4E9C-8CD3-CF6E4FF96FF9\% 7 D/s_2014_562.pdf >.

31 Tatiana Carayannis and Louisa Lombard, 'A Concluding Note on the Failure and Future of Peacebuilding in CAR', in Tatiana Carayannis and Louisa Lombard (eds), Making Sense of the Central African Republic (Chicago: University of Chicago Press, 2015) 324.

32 SC Res 2149, UnsCOR, $7153^{\text {rd }} \mathrm{mtg}$, S/RES/2149 (10 April 2014).

33 Ibid., [24].

34 See, CAR Panel Report, above n 2; Tatiana Carayannis and Mignonne Fowlis, 'Lessons from African Union - United Nations cooperation in peace operations in the Central African Republic' (2017) 26(2) African Security Review, pp. 220-236.

Ibid.
} 
that MINUSCA, amongst other tasks, has been specifically mandated 'to provide specific protection, for women and children affected by armed conflict....'36

Allegations against the MISCA AU force of human rights violations were referred by the UN office in CAR at the time to the MISCA Force Commander, from time to time, according to the Head of the Human Rights and Justice Section of MINUSCA. He noted that there was no parallel investigation by the Human Rights component of MINUSCA. ${ }^{37}$ Indeed, as noted by the CAR Panel Report, UN reporting of allegations of human rights violations by Chadian troops deployed under the AU's MISCA operation, was the cause of considerable tension between the Chadian government and MINUSCA and OHCHR, resulting in Chad withdrawing its troops from CAR. ${ }^{38}$ Post the re-hatting process, the CAR Panel Report, amongst other sources, have documented numerous allegations of human rights violations, including SEA by peacekeepers. Leading one to link this, at least to an extent, with the adequacy of vetting and screening processes. This leaves us in a paradoxical situation: adequately addressing human rights abuses by peacekeepers may ultimately lead to insufficient troops on the ground to protect civilians from human rights and IHL violations by others. The HRDDR in effect requires screening, monitoring and vetting processes by the UN when supporting or re-hatting troops from an external organization. The policy appears to recognize, to an extent, the aforementioned conundrum, allowing the UN some leeway in the refusal of troops from sending states in light of human rights violations. The HRDDR will be discussed in Section III. However, even with respect to UN contingents, the UN relies on vetting processes of states contributing personnel, given its lack of capacity to vet individual contingent members alone, ${ }^{39}$ and the $\mathrm{AU}$ is yet another step removed.

As recently as May 2017 Ugandan troops deployed as part of the AU's Regional Task Force to CAR were accused of SEA, perpetrated since 2015, and involving

${ }_{3} 6$ See further, Paul Williams, "The African Union Mission in Somalia and Civilian Protection Challenges' (2013) 2(2) International Journal of Security and Development $<\mathrm{http}$ ://www .stabilityjournal.org/articles/10.5334/sta.bz/> ('The African Union Mission in Somalia').

37 The Power these Men have Over Us: Sexual Exploitation and Abuse by African Union Forces in Somalia, Human Rights Watch (8 September 2014) ('HRW Report'), Appendix C, Head of the Human Rights and Justice Section, MINUSCA, Second Response to the Report of the Panel <https://www.hrw.org/report/2014/og/o8/power-these-men-have-over-us/ sexual-exploitation-and-abuse-african-union-forces $>$.

$3^{8} \quad$ CAR Panel Report, above n 2, p. 51.

39 Kevin Sieff, 'UN discovers that some peacekeepers have disturbing pasts', Washington Post (online) 26 December 2016 <https://www.washingtonpost.com/world/africa/they -served-an-abusive-government-the-un-made-them-peacekeepers-anyway/2016/12/23/o 5coa5ad-108f-46b9-b6f7-5f2303f6cdfe_story.html?utm_term=.effa354fdda8>. 
at least thirteen women and girls. ${ }^{40}$ Fifteen women and girls interviewed by HRW stipulated that they had become pregnant as a result of SEA by these troops, and that they were left without any support from the fathers. This was often coupled with stigmatization for having given birth to 'Ugandan babies', leading to further socio-economic hardships. Other serious crimes allegedly perpetrated by peacekeepers under AU command in CAR, have included alleged killings. ${ }^{41}$ Chad withdrew its peacekeepers in 2014, after an incident in which Chadian soldiers fired into a crowd of civilians, killing 25 , and injuring approximately 100 others. ${ }^{42}$ Hundreds of Congolese troops from the UN operation in the DRC have been repatriated in 2016/2017 linked to allegations of SEA and poor discipline. ${ }^{43}$

\section{AмIsом Operation Somalia}

AMISOM is an AU operation, operating under an AU and UN mandate in countering insurgency by Al Shabab in Somalia. ${ }^{44}$ A large portion of funding for AMISOM has come from the UN and EU. The operation has been present in Somalia since 2007. As of 2017, there were over 20,000 AM ISOM troops deployed to Somalia; only $3.5 \%$ are female. ${ }^{45}$ AMIsom's deployment, in addition to unilateral interventions by Kenya and Ethiopia, have proven integral to shifting

40 Central African Republic: Ugandan Troops Harm Women, Girls, 15 May 2017, Human Rights Watch <https://www.hrw.org/news/2017/05/15/central-african-republic-ugandan-troops -harm-women-girls $>$.

41 Ibid; Somalia: AU Forces Linked to Wedding Killings, 13 August 2013, Human Rights Watch <https://www.hrw.org/news/2015/o8/13/somalia-au-forces-linked-wedding-killings>; Hamza Mohamed, 'AU Troops Gun Down Unarmed Civilians in Somalia', Al Jazeera (online), 22 July 2015 <http://www.aljazeera.com/news/2015/07/au-troops-gun-unarmed-civi lians-somalia-150721132538943.html>; Central African Republic: Murder by Peacekeepers Discovery of Mass Grave Provides New Evidence, 7 June 2016, Human Rights Watch <https:// www.hrw.org/news/2016/06/o7/central-african-republic-murder-peacekeepers >.

42 Carayannis and Fowlis, above $\mathrm{n} 34$.

43 Leaked memo, MINUSCA Force Commander to DPKO Military Advisor for Peacekeeping Operations, 12 May 2017, p. 8 <https://static1.squarespace.com/static/514a0127e4bo4d $7440 \mathrm{e}$ 8045d/t/593704c246c3c49oc3eeob24/1496777924587/CAR+memo.pdf> and 14-16 March <https://static1.squarespace.com/static/514a0127e4bo4d7440e8045d/t/593704a2579fb3 7a23567889/1496777906180/MINUSCA+ORA.pdf >; See also, Code Blue website <http:// www.codebluecampaign.com/press-releases/2017/6/6>.

44 AMISOM <http://amisom-au.org/amisom-mandate/ $>$.

$45 A U$ Peace and Security Council open session on the role of women in protecting lives in challenging security environments in Africa, Bulletin, January-February 2017, United Nations Office to the African Union, p. 3 <https://unoau.unmissions.org/sites/default/files/o1 _unoau_bulletin_jan_feb_2017_14mari7.pdf $>$. 
the clutches of al-Shabaab from Mogadishu, and enabling the beginnings of state-building, re-instatement of the rule of law, and it is hoped, through the new Federal Government at of 2012, re-establishment, of some level of stability incrementally in the various regions throughout Somalia. Protection of Civilians was inserted in the mandate of AMISOM in $2013 \cdot{ }^{46}$ Nevertheless, AM ISOM has been criticized for a range of IHL and IHRL violations, including for its indirect fire policies resulting in civilian deaths (albeit these have since been reformed including through revisions to the Rules of Engagement) but also SEA. ${ }^{47}$

A Human Rights Watch ('HRW') Report, titled 'The Power These Men Have Over Us - Sexual Exploitation and Abuse by AU Forces in Somalia', was released on 8 September 2014. The Report documented an array of SEA allegations against $\mathrm{AU}$ peacekeepers deployed to AMISOM, ranging from rape to transactional sex, and rape disguised as prostitution, including through the use of local intermediaries. A number of women were allegedly exposed to STIs. ${ }^{48}$ Ten incidents of sexual abuse and fourteen of sexual exploitation were, in particular, were alleged in the HRW Report. Many of these were reported to have taken place in AMIsom structures or camps. ${ }^{49}$ The youngest complainant, a 12 year-old girl, alleged that a Ugandan soldier had raped her in 2013. ${ }^{50}$ The majority of allegations set out in the HRW report involved personnel of the Ugandan People's Defence Forces and the Burundian National Defense Forces. ${ }^{51}$ Only two of the victims, whose cases were investigated by HRW, filed official complaints to Somali authorities. This was likely given the risk of severe social stigma, ostracization from their communities and families, ${ }^{52}$ safety concerns, lack of safe houses, ${ }^{53}$ fear or reprisals, fear of prosecution by Somali authorities, ${ }^{54}$ and for some income loss where money was exchanged. The UN,

46 Williams, 'The African Union Mission in Somalia', above $\mathrm{n} 36$.

47 See further, Erin Weir, Policies that Protect: The African Union and the Protection of Civilians, Policy Brief No. 7, Norwegian Institute of International Affairs, $2013<$ https://www .files.ethz.ch/isn/168422/NUPI\%2oPolicy\%2oBrief-7-13-Weir.pdf>.

48 HRW Report, above n 37, pp. 3-5, 9.

49 Ibid., p. 5.

5o Ibid., p. 39 .

$51 \quad$ Ibid.

52 Marion Pratt and Leah Werchick, Sexual Terrorism: Rape as a Weapon of War in Eastern Democratic Republic of the Congo, USAID/DCHA Report (18 March 2004) <http://pdf.usaid .gov/pdf_docs/Pnadk346.pdf>.

53 'Engaging communities in promoting women's rights, security and peace in South Central Somalia' (Seminar, cisP and International Alert, 30 October 2015). HRW Report, above n 37, pp. 3, 10, 67, 72 . 
Legal Action Worldwide and others have documented further allegations of sexual violence by АM Is

AM ISOM did initially respond to H RW's concerns, but subsequently was cynical as to the veracity of claims and critical of the overall report and the credibility of HRW's methodology. Moreover the AU was critical of HRW's refusal, due to concerns for confidentiality and safety of the victim, to provide dates, names of victims, alleged perpetrators and witnesses. Generally the above allegations are disputed by АMISом. The AU does rightly stress that the majority of АM ISOM troops are not likely to be involved in SEA. Moreover, the AU emphasized that the AMISOM operation as a whole is essential to the security of the Somali people, re-establishment of the rule of law, and re-building of state institutions in Somalia. ${ }^{56}$ For a variety of reasons accountability with respect to the majority of the allegations has not arisen, with the AU's investigators unable to gather sufficient evidence. Subsequent investigations have been conducted by AмISOм into some incidents of sexual violence alleged against AMISOM personnel, but some troop-contributing states refused to cooperate and follow-up. ${ }^{57}$ It is not apparent that $\mathrm{AU}$ has conducted a detailed overall examination of the prevalence of abuse throughout its peace operations more generally, created statistics, and/or seriously addressed the regulatory framework governing this type of abusive conduct.

\section{AU Regulatory Frameworks}

\section{IHL and IHRL}

Needless to say, many acts falling within the definitions of sexual exploitation and abuse ('SEA') violate international law, in particular various human rights and international humanitarian law treaties and instruments, many of which are ratified by AU deploying states. These include, but are not limited to, the violations of CEDAW, CRC, Torture Convention, four Geneva Conventions

55 See, e.g. Legal Responsibility and Accountability of the United Nations for Sexual Violence Committed by Security Forces in Somalia, Legal Action Worldwide, Position Paper (2014) pp. 5-6 <http://legalactionworldwide.org/wp-content/uploads/2014/11/UN-Legal -Responsibility-and-Accountability-of-the-United-Nations-for-Sexual-Violence-Commit ted-by-Security-Forces-in-Somalia.pdf> ('Legal Responsibility and Accountability').

56 See, Letter to HRw from the Special Representative of the Chairperson of the Commission (SRCC) for Somalia and Head of AMISOM, 19 October 2014, АM ISOM/НОM/14/343.14.

57 SC Res 2232, extending the mandate of Unsom. SC Res 2232, Un SCOR, $7491^{\text {st }} \mathrm{mtg}$, UN Doc S/RES/2232 (28 July 2015). 
of $1949^{58}$ ('GCs') and their Additional Protocols of $1977,{ }^{59}$ the Protocol to the African Charter on Human and People's Rights on the Rights of Women in African ('Maputo Protocol'), the AU Convention for the Protection and Assistance of Internally Displaced Persons in Africa ('Kampala Convention'), the African Charter on the Rights and Welfare of the Child, the Un Security Council Resolutions on Women, Peace and Security and those on children and armed conflict, and the Solemn Declaration on Gender Equality in Africa ('SDGEA') ${ }^{60}$ For instance, Article 27 of GC IV, provides that:

Protected persons ... shall at all times be humanely treated, and shall be protected especially against acts of violence or threats thereof and against insults or public curiosity. Women shall be especially protected against attack on their honour, in particular, against rape, forced prostitution, or any form of indecent assault. ${ }^{61}$

Numerous academics, practitioners and policy makers have engaged in detailed discussions of how sexual offences may constitute war crimes and human rights violations, and call for special protections of women and children in

58 Article 2, Convention for the Amelioration of the Conditions of the Wounded in Armed Forces in the Field, opened for signature 12 August 1949, 75 UNTS 31 (entered into force 21 October 1950) ('GC I'); Article 2, Convention for the Amelioration of the Conditions of the Wounded, Sick and Shipwreaked Members of the Armed Forces at Sea, opened for signature 12 August 1949, 75 UnTs 85 (entered into force 12 October 1950) ('GC II'); Article 2, Convention Relevant to the Treatment of Prisoners of War, opened for signature 12 August 1949, 75 UNTS 135 (entered into force 12 October 1950) ('GC III'); Article 2, Convention Relevant tot the Protection of Civilian Persons in Time of War, opened for signature 12 August 1949, 75 UNTS 287 (entered into force 21 October 1950) ('GC IV') ('Geneva Conventions').

59 Protocol Additional to the Geneva Conventions of 12 August 1949, and Relating to the Protection of Victims of International Armed Conflicts, opened for signature 12 December 1977, 1125 UNTS 3 (entered into force 7 December 1978) ('AP I'); Protocol Additional to the Geneva Conventions of 12 August 1949, and relating to the Protection of Victims of Non-International Armed Conflicts, opened for signature 8 June 1977, 1125 UNTs 609 (entered into force 7 December 1978) ('AP II').

6o SC Res 1325, UN SCOR, 55th sess, 4213th mtg, UN Doc S/RES/1325 (31 October 2000); See also, sC Res 1888, unsCor, 6195th mtg, Un Doc s/Res/1888 (30 September 2009); SC Res 1960, UnSCOR, 6453th mtg, UN Doc s/RES/196o (16 December 2010); SC Res 1889, UNSCOR, 6196th mtg, Un Doc S/RES/1889 (5 October 2009); SC Res 2122, UNSCOR, 7044th $\mathrm{mtg}$, UN Doc S/RES/2122 (18 October 2013); sC Res 1882, Un SCOR, 6176 $6^{\text {th }} \mathrm{mtg}$, UN Doc S/RES/1882 (4 August 2009).

$61 \quad G C I V$. 
armed conflict and in peace. ${ }^{62}$ Of course, the application of these instruments is froth with conceptual and legal difficulties. Moreover, their application is context-based and will depend on an array of variables, such as the existence of armed conflict and type of conflict; whether peacekeepers are considered party to an armed conflict; attribution of responsibility; and for human rights instruments, their extraterritorial application and whether they impose any substantive obligations on a state or, indeed, international or regional organization. ${ }^{63}$ This in turn has implications for state and organizational responsibility under public international law, with substantive violations hinged on the content of their international legal obligations, specific to the particular state or entity. Notably, there were no legal advisors specifically deployed to advise on IHL to AMISOM until 2010. ${ }^{64}$ In terms of attribution of responsibility re-hatting of troops and the HRDDP, may add another layer of complexity in terms of legal obligations and dual and multiple lines of responsibility of states, the $\mathrm{AU}$, and the $\mathrm{UN}$, in addition to parallel criminal and disciplinary liability of individuals under domestic and international law. As the ICRC, for instance, stipulates in its Commentary to Article 29 of GC IV, 'if the author of the act contrary to international law is an agent of the State, it is no longer his

62 Burke, Sexual Exploitation and Abuse: Moving Beyond, above n 1, Ch. 3; Judith Gardam, 'Women, Human Rights and International Humanitarian Law' (1998) 324 International Review of the Red Cross 421; Kelly Askin, 'Prosecuting Wartime Rape and Other Gender Related Crimes under International Law; Extraordinary Advances, Enduring Obstacles' (2003) 21 Berkeley Journal of International Law 313; Christine Chinkin, 'Rape and Sexual Abuse of Women in International Law' (1994) 5 European Journal of International Law 3; Theodor Meron, 'Rape as a Crime Under International Humanitarian Law' (1993) 87 American Journal of International Law 424; Catherine Niarchos, 'Women, War and Rape: Challenges Facing the International Tribunal for the Former Yugoslavia' (1995) 17 Human Rights Quarterly 672; Naomi Cahn, 'Beyond Retribution and Impunity: Responding to War Crimes of Sexual Violence' (2005) 1 Stanford Journal of Civil Rights and Civil Liberties 240.

63 Burke, Sexual Exploitation and Abuse: Moving Beyond, above n 1, Chs 3 and 6; Fons Coomans and Menno Kamminga (eds), Extraterritorial Application of Human Rights Treaties (Intersentia, 2004); Ralph Wilde, 'Triggering State Obligations Extraterritorially: The Spatial Test in Certain Human Rights Treaties' (2007) 40 Israeli Law Review 503; Michal Gondek, The Reach of Human Rights in a Globalising World: Extraterritorial Application of Human Rights Treaties (Intersentia, 2009); Mosche Hirsch, The Responsibility of International Organizations Toward Third Parties: Some Basic Principles (Dordrecht: Martinus Nijhoff, 1995); Dannenbaum, above n 13, p. 113; Boris Kondoch, 'The Responsibility of Peacekeepers, Their Sending States and International Organizations', in Gill and Fleck (eds), The Handbook of the International Law of Military Operations (Oxford University Press, 2010) 515 .

64 Williams, 'The African Union Mission in Somalia', above n 36. 
responsibility alone which is involved, but also that of the State, which must make good the damage and punish the offender.' 65 Article 146 of GC IV requires states to 'undertake to enact any legislation necessary to provide effective penal sanctions for persons committing, or ordering to be committed, any of the grave breaches'. Moreover, it encompasses a search for 'grave breach' culprits' obligation on states, and a 'prosecute or extradite' requirement. ${ }^{66}$ It should be borne in mind that states carry their IHL and, to an extent, their IHRL obligations with them. Although any level of responsibility will depend on an act or omission being attributed to that state, and the extraterritorial application of those human rights instruments that they have ratified. It is beyond the scope of this current paper to address the implications of these legal regimes for the various actors and the intricacies of applying them. Nevertheless, these are very real issues for the UN and $\mathrm{AU}$, and partnerships between them, going forward and in light of recent developments in the articulation of international organization responsibility, in particular by the International Law Commission. ${ }^{67}$

\section{AU'S SEA Regulatory and Policy Framework}

Reverting back to the AMISOM operation and the 2014 HRW report detailing allegations of SEA by AU peacekeepers in Somalia. As mentioned, the report and correspondence between the AU and HRW are among the few sources of information on how the AU might respond to allegations of SEA by AU peacekeepers. Yet these documents to a large extent appear AM ISOM specific, and many actions taken by the AU appear reactionary as opposed to pre-emptive in dealing with SEA.

There are several levels of investigation into misconduct reported to occur in the context of AU operations, with AMIsom being a case in example. An investigation may be conducted by a Board of Inquiry ('Вог') at contingent level or Headquarters level. SEA allegations give rise to Headquarters level investigation. Disciplinary Boards are also established where intra-AмISOM complaints arise, and may deal with something like sexual harassment within AMISOM but not with SEA involving the local population. These mechanisms are $a d$ hoc responses to allegations of offences being committed, and they lack transparency as to results external to the $\mathrm{AU}$. The mission and contingent BOIs

65 Commentary on the Geneva Conventions, ICRC.

66 GC IV.

67 For an analysis of how this operates in the context of IHL and IHRL violations by UN peacekeepers and state and international organization responsibility (which can to an extent be applied by analogy, although the UN has done a lot more to regulate SEA than the $\mathrm{AU}$ ), see, Burke, Sexual Exploitation and Abuse: Moving Beyond, above n 1, Chs. 3 and 5 . 
are finalized by mission $\mathrm{HQ}$ and are then supposed to be communicated to the AU's Peace Support Operations Division ('PSOD'). BOIs established at contingent level are meant to report back to the Office of the Special Representative of the Chairperson of the Commission. ${ }^{68}$ Questions arise as to the legal standing of the proceedings conducted by these воIs and resultant outcomes. For instance, do they mirror the administrative measures that can be conducted by the UN Office of Internal Oversight Service ('oIOs') or BoIs? ${ }^{69}$ If an allegation is substantiated presumably it will be referred to the troop-contributing state or police -contributing state (or perhaps host state) for subsequent prosecution, but how it this process dealt with and monitored by the AU and mission? How are outcomes communicated to victims and the civilian population, and indeed local counterparts being trained by AU personnel? As HRW noted, it is unlikely that those, part-taking in Ам ISOм воIs had specialized skills in the area of SEA. ${ }^{70}$ Justice Rapid Response ('JRR') or similar training body could assist with training of AU personnel on investigating sexual and gender-based violence so that these could be deployed to assist with investigations in the field, or JRR could lend roster personnel. ${ }^{71}$

Protection of civilians is set out in Article $4(\mathrm{~h})$ of the AU's Constitutive Act and it has appeared to varying degrees in some AU peace operation mandates, most explicitly in the African led-Peace Operation to Sudan ('AMIs') deployed in 2004, which was subsequently integrated into the AU-UN Hybrid Operation in Darfur ('UNAMID'). ${ }^{72}$ In a 2012 press statement, the AU Peace and Security Council stressed the importance of mainstreaming protection of civilians considerations across its peace operations. ${ }^{73}$ This is also integrated into Rules of Engagement, for instance with respect to Ам ISом. ${ }^{74}$ Protection of civilians

68 HRW Report, above n 37, p. 86, Letter Annexed to HRw Report letter, Annex 3, p. 6.

69 Report on the Activities of the Office of Internal Oversight Services, Report of the SecretaryGeneral, UN GAOR, $65^{\text {th }}$ sess, Agenda Item 141, UN Doc A/65/271 (Part I) (9 August 2010) [16]-[17]; Burke, Sexual Exploitation and Abuse: Moving Beyond, above n 1, pp. 51-54.

$70 \quad$ HRW Report, above n 37, pp. 35-36, 47.

71 JRR-UN Women partnership, which has resulted in the training and creation of a certified roster of experts on sexual and gender-based violence. See, Justice Rapid Response <http://www.justicerapidresponse.org/>.

72 See further, Williams, 'The African Union Mission in Somalia', above n 36.

73 See also, Gustavo De Carlvalo and Andreas Øien Stensland, 'Protection of Civilians in Peacekeeping in Africa: Context and Evolution', in Vasu Grounden (ed), Protection of Civilians in Peacekeeping in Africa, (Issue 2, Conflict Trends, 2012) p. $10<$ http://dspace .africaportal.org/jspui/bitstream/123456789/33159/2/Conflict\%2oTrends\%2oIssue\%2o 2\%202012.pdf?1>.

74 Williams, 'The African Union Mission in Somalia', above n 36. 
inevitably incorporates protection from sexual violence more broadly. Nevertheless, as noted by Williams, protection of civilians in the context of UN operations is more straight-forward than in the context of many AU operations. This is because $\mathrm{AU}$ operations often involve more robust forms of peace operations, including use of force and counter-insurgency operations. ${ }^{75}$ Nevertheless, this should not impact on the protection of civilians in so far as it incorporates sexual violence, in particular by AU peacekeepers themselves.

The AU stipulated in a 2014 letter to HRW that it is endeavoring to integrate gender considerations with respect to women in conflict and peace situations across three thematic areas, namely: '(1) prevention of gender-based violence ("GBV"); (2) effective participation in peace processes; and (3) protection of women in conflict areas. ${ }^{.76}$ The UN Office of the Special Representative of the Secretary-General ('SRSG') on Violence in Conflict and the AU Commission have drawn up a Framework of Cooperation Agreement 'Concerning the Prevention and Response to Conflict-related Sexual Violence in Africa. ${ }^{77}$ The Framework Agreement refers to collaboration between the AU's Peace and Security Department and the SRSG across a number of priority areas, including: 'combatting impunity and promoting accountability as a critical aspect of deterrence and prevention', in addition to fostering responsibility for SGBV; undertaking 'capacity-building and training to enhance response'; 'empowering women and girls'; and 'countering the stigma of survivors'; in addition to the provision of some supports for victims of conflict - related SGBV. The AU has noted, in its 2015 Common African Position on the UN Review of Peace Operations, the need for training of $\mathrm{AU}$ peacekeepers in the areas of Women Peace and Security, including on SEA, and stressed the need for accountability of those that violate members of the local population. ${ }^{78}$ The Framework includes a number of advocacy commitments including advocating amongst AU member states to more effectively address SGBV, put in place adequate legislation to govern such, and enhance their criminal justice systems' responses. It places

75 Williams, 'The African Union Mission in Somalia', above n 36; Joseph Bialke, 'United Nations Peacekeeping Operations: Applicable Norms and the Application of the Law of Armed Conflict' (2001) 50 Air Force Law Review 12.

$7_{6}$ HRW Report, above n 37, p. 81; Letter Annexed to HRW Report letter, Annex 3, p. 1.

77 Framework of Cooperation between the United Nations Office of the Special Representative of the Secretary-General on Sexual Violence in Conflict and the African Union Commission Concerning the Prevention and Response to Conflict-Related Sexual Violence (31 January 2014) <http://www.peaceau.org/uploads/au-un-framework-of-cooperation-on-csvr.pdf> ('Framework Agreement').

78 Common African Position on the AU Review of Peace Operations, AU Peace and Security Council, 202 ${ }^{\text {nd }} \mathrm{mtg}$, AU Doc PSC/PR/2(DII) (29 April 2015) p. 14. 
a monitoring and reporting obligation on the SRSG and the AU with respect to conflict-related SGBV. Of particular relevance here, is the specific mention of peacekeepers deployed under the $\mathrm{AU}$ and their responsibilities. It provides for the 'raising of awareness of the African Union Code of Conduct for African Union Peace Support Operations to prevent conflict-related sexual violence'. It calls on the need for 'Popularizing the African Union Code of Conduct for African Union Peace Support Operations (PsOs) as a disciplinary rule to sensitize stakeholders and to prevent conflict-related sexual violence. ${ }^{79}$ The Agreement finally calls on the AU to establish a Focal Point for addressing conflict-related SGBV. An annual implementation plan is supposed to be produced by the SRSG and AU. This plan should specifically address how the AU will create structures, policy and processes to better regulate possible AU peacekeeper involvement in SEA.

The AU to an extent conflates the issues of SEA and conflict-related SGBV. Of course the former to some extent can be subsumed in the later, but the later will not necessarily capture the full extent and distinguishing features of at least some aspects of SEA. Moreover, it means subsuming reports of SEA in the broader context of SGBV in mission host states, be it perpetrated by local militias, local armed forces or police, by civilians and so forth. While SEA can and does incorporate conflict-related SGBV, it is broader, and conflict-related SGBV is dependent on abusive conduct being related to the conflict. Although, one could argue that it is volatile conflict environments and weak or non-existent rule of law that are enabling factors for such abuse to occur. This is tied to the presence of peacekeepers in the first instance. While there is no universally accepted definition of conflict-related SGBV, it was defined by SG Report conflict-related sexual violence according to the UN's 2017 Glossary of Terms is defined as:

rape, sexual slavery, forced prostitution, forced pregnancy, forced abortion, enforced sterilization, forced marriage and any other form of sexual violence of comparable gravity perpetrated against women, men, girls or boys that is directly or indirectly linked (temporally, geographically or causally) to a conflict. This link with conflict may be evident in the profile of the perpetrator (often affiliated with a State or non-State armed group), the profile of the victim (who is frequently a member of a persecuted political, ethnic or religious minority), the climate of impunity (which is generally associated with State collapse), cross-border consequences

79 Framework Agreement, above n 76, Prov 3; Conflict-related sexual violence: Report of the Secretary-General, un SCOR, un Doc s/2016/361 (20 April 2016). 
(such as displacement or trafficking in persons) and/or violations of the terms of a ceasefire agreement. ${ }^{80}$

The UN notes that troop-contributing and police-contributing states' involvement in 'grave violations against children and/or conflict-related sexual violence and that those complicit will be prohibited from participating in United Nations peace operations.' ${ }^{81}$ States have to prove that measures to end involvement of their personnel have been implemented if they are to be delisted from an Annex of state and non-state party involvement in the SG's annul report. The AU should extend this to states deploying to AU operations. However, for the most part those listed are unlikely to form part of deployments to UN operations at the very least.

Article 4(1) of AU's Constitutive Act incorporates promotion of gender equality within the organization's aims. The AU has established the African Union Women Gender and Development Directorate ('AU WGDD'), which has developed a plan on centralizing gender in the work of the AU, including peace operations. Moreover, the Directorate had developed a Gender Training Manual for African Peacekeepers, which incorporates topics such as conflictrelated SGBV, child protection, SEA, and the draft code of conduct for PSCS. It is less clear how the content is disseminated, what time is devoted to this, and whether this training is a deployment pre-requisite. ${ }^{82}$ Kasumba and Lotze observe that 'the manual was developed in a policy lacuna, it also was unable to provide effective guidance for AU PSO personnel on practical issues such as monitoring, reporting and evaluation. ${ }^{83}$ The Directorate itself suffers from poor funding, undermining its ability to effectively implement its mandate. ${ }^{84}$

8o Conflict-related sexual violence: Report of the Secretary-General, UN SCOR, UN Doc s/2016/361 (20 April 2016).

81 Conflict-related sexual violence: Report of the Secretary-General, UN SCOR, UN Doc S/2017/249 (15 April 2017) p. 3.

82 African Union Commission, Implementation of the Women Peace and Security Agenda in Africa (Office of the Special Envoy on Women, Peace and Security of the Chairperson of the African Union Commission, Ethiopia, 2016) p. 35 <http://www.un.org/en/africa/osaa/ pdf/pubs/2016womenpeacesecurity-auc.pdf> ('Implementation of the Women Peace and Security Agenda').

83 Yvonne Kasumba and Walter Lotze, Mainstreaming Gender into African Union Peace Support Operations: Why Are We Getting it Wrong, 2 Conflict Trends (2013, ACCORD) pp. $23,27$.

84 Abdullah, above n 20, pp. 23-24; United Nations Office to the African Union, AU Peace and Security Council open session on the role of women in protecting lives in challenging security environments in Africa, AU Doc PSC/PR/COMM.(DCLIX) (16 February 2017) <http://www.peaceau.org/uploads/psc-659comm-role-of-women-16-2-2017-eng.pdf>. 
According AMISOM emphasis has been put on pre-deployment training and sending state engagement regarding their responsibility to hold perpetrators to account. ${ }^{85}$ The AU appointed a Special Envoy for wPS, Madame Benita Diop, in 2014, ${ }^{86}$ but it is not apparent what work the Special Envoy has conducted specifically on SEA in this broader context. The Envoy has raised the issue of SEA by AU peacekeepers, noting that SEA occurs irrespective of AU zerotolerance policies (as it does in the UN). She recommended that AU Member States increase the number of women in their security forces by 2020 through the use with quotas, in addition to conducting SGBV and SEA training for all peacekeepers. The Envoy further recommended the creation of a monitoring mechanism and structures at country level, and 'clear conduct and disciplinary policies for AU-led peace operations. ${ }^{\prime 87} \mathrm{Of}$ course there are close synergies between the WPS discourse and SEA by peacekeepers, yet the WPS agenda has been kept largely separate from the SEA debate. ${ }^{88}$

The AU also has established Gender Units in peace operations (at least with respect to АMISOM) and deployed women and child protection officers to missions. It has also put in place Conduct and Discipline Officers at HQ and in peace operations. ${ }^{89}$ The AU has being developing a Protection of Civilians Policy, releasing a draft set of Guidelines for the Protection of Civilians in African Union Peace Support Operations in 2010.90 At the outset the guidance states

85 HRW Report, above n 37, AU response letter, Annex 3, pp. 3-4.

86 Bineta Diop, Special Envoy on Women, Peace and security, 13 July $2013<$ http://www .peaceau.org/en/page/40-5676-static-bineta-diop>.

87 United Nations Office to the African Union January-February 2017 AU Peace and Security Council open session on the role of women in protecting lives in challenging security environments in Africa, p. $3<$ https://unoau.unmissions.org/sites/default/files/o1_unoau _bulletin_jan_feb_2017_14mar17.pdf $>$.

88 For discussion on how this undermines the wPS agenda, see, Jasmine Kim Westendorf, 'WPS, CRSV and Sexual Exploitation and Abuse in Peace Operations: Making sense of the missing links' (LSE Centre for Women Peace and Security, 2017) <http://www.lse.ac.uk/ women-peace-security/assets/documents/2017/wpsgWestendorf.pdf $>$.

$89 \quad$ HRW Report, above n 37, p. 83, AU response letter, Annex 3, p. 3.

9o Draft Guidelines for the Protection of Civilians in African Union Peace Support Operations, African Union (Australian Civil Military Centre, 2012) <http://www.peaceau.org/uploads/ draft-au-poc-guidelines-english.pdf $>$; The guideline draws inspiration from a number of prior documents, including: Draft UNMISs Protection of Civilians Strategy Concept, 12 May 2009; UnAmid Mission Directive No: 2009/o1: Protection of Civilians in Darfur; the MONUC/ Protection Cluster Protection in Practice: Practical Protection Handbook for Peacekeepers <http://www.operationspaix.net/DATA/DOCUMENTTEXTE/6933.pdf>; Draft Code of Conduct for the Armed Forces and Security Services of West Africa, Ecowas Committee of Experts, April 20o6; Adedeji Ebo, 'Towards a Code of Conduct for Armed and Security 
that protection of civilians by AU peacekeepers means that their actions must adhere to relevant international law, including IHL, human rights law and refugee law. Of particular importance are the protection needs of vulnerable groups, including children, and the on training of PSo personnel. ${ }^{91}$ Yet, no specific references are made to the prohibition of SEA by peacekeeping personnel.

The AU's Gender, Peace and Security Programme (2015-2020), launched in 2014, is targeted at supporting implementation of gender mainstreaming across AU activities, including through the provision of support to divisions of the Peace and Security Department. ${ }^{92}$ In 2016 the 2016-2020 African Peace and Security Architecture Roadmap commenced its roll out. Amongst the highlighted priorities is gender mainstreaming. Gender sensitive indicators are to be used in monitoring the performance of Gender, Peace and Security outcomes. ${ }^{93}$ These, in addition to the AU's Special Envoy on wPS, should act as a monitoring, reporting and accountability tool in ensuring better WPS outcomes. This should, include sexual offences by AU peacekeepers within its remit.

UNSCR 2242 (2015) emphasizes the importance of regional organizations in advancing the WPS agenda. Developing best practice in the area of SEA by peacekeepers would feed into demonstrating the AU's commitments in this regard. SC UNSCR 2272 (2016) sets out a number of measures to respond to SEA in peace operations, including that those deploying with un support adopt 'adequate measures to prevent and combat impunity for sexual exploitation and abuse by their personnel'; investigate and prosecute; and repatriate units there is credible where there is credible evidence of abuse. ${ }^{94}$ Amongst its measures,

Forces in Africa: Opportunities and Challenges', Geneva Centre for the Democratic Control of Armed Forces Policy Paper, March $2005<\mathrm{http}$ //dspace.africaportal.org/jspui/ bitstream/123456789/27485/1/Towards\%20a\%2oCode\%20of\%2oConduct\%2ofor\%2o Armed\%20and\%2oSecurity\%2oForces\%2oin\%2oAfrica\%20-\%20Opportunities\%20 and\%20Challenges.pdf?1>.

91 Draft Guidelines for the Protection of Civilians in African Union Peace Support Operations, African Union (Australian Civil Military Centre, 2012) <http://www.peaceau.org/uploads/ draft-au-poc-guidelines-english.pdf> [11]; Report of the Secretary-General on options for authorization and support for African Union peace support operations, UN SCOR, UN Doc s/2017/454 (26 May 2017) [45]; sC Res 2182, UNSCOR, $7286^{\text {th }} \mathrm{mtg}$, UN Doc s/REs/2182 (24 October 2014) [33].

92 African Union Commission, Implementation of the Women Peace and Security Agenda, above $\mathrm{n} 8 \mathrm{o}$.

93 Ibid., p. 7 .

94 SC Res 2272, UNSCOR, $7643^{\text {rd }} \mathrm{mtg}$, s/RES/2272 (11 March 2016)[7]-[8]. 
AMIsom issued Force Commander's Disciplinary Directive on Conduct of Military Actions. ${ }^{95}$ These remain internal to the organization.

There are reports of the AU working on a policy framework to better address SEA by its peacekeepers, and a whistleblower policy, yet it does not appear to have produced significant advancements in this regard. ${ }^{96}$ There does exist an Ам гом specific Policy on Prevention of Sexual Exploitation and Abuse, which applies to both uniformed and non-uniformed AMISOM personnel. The AмIsom Guide on its Policy on Prevention and Response to SEA, stipulates that 'Personnel must report any concerns or suspicions they have regarding possible violations of this SEA Policy via AMISOM's reporting mechanism.' Every AMISOM component is supposed to establish appropriate reporting mechanisms for SEA. ${ }^{97}$ It is not apparent to what extent this has been implemented. Moreover, there is no permanent independent investigative mechanism or anything akin to the UN's OIOS, the UN's administrative investigative body charged with conducting preliminary fact-finding enquiries into crimes by peacekeepers and administrative investigations (including with respect to SEA). ${ }^{98}$

AMISOM has established gender focal points within its contingents and a Gender Unit at Headquarters, which has initiated training on gender issues and SEA for personnel deployed to Somalia. ${ }^{99}$ There is a PSOD Conduct and Discipline Advisor and a strategy on conduct and discipline was apparently devised at HQ level for AU peace operations based on several engagement areas, including: leadership engagement and oversight, awareness raising

95 The African Union strongly rejects the Conclusions contained in the Report of the Human Rights Watch on allegations on sexual exploitation and abuse by АмIsом (8September 2014) African Union <http://www.peaceau.org/en/article/the-african-union-strongly-rejects -the-conclusions-contained-in-the-report-of-the-human-rights-watch-on-allegations-on -sexual-exploitation-and-abuse-by-amisom>.

96 Human Rights Watch, Central African Republic: Ugandan Troops Harm Women, Girls, above $\mathrm{n} 40$.

97 Аміsом Gender Unit, Easy-to-Read Guide on Амisom: Policy on Prevention and Response to Sexual Exploitation and Abuse (September 2013) 3.

98 SG Report - Strengthening Investigations, UN GOAR, 62 $2^{\text {nd }}$ sess, Agenda Items 126, 128 and 140 UN Doc A/62/582 (12 December 2007); 2008 Manual on Policies and Procedures Concerning the Reimbursement and Control of Contingent-Owned Equipment of Troop/Police Contributors Participating in Peacekeeping Missions, $5^{\text {th }}$ Comm, $63^{\text {rd }}$ sess, Agenda Item 132, UN Doc A/C.5/63/18 (29 January 2009) Ch. 9, Annex F.

99 'Newly deployed military officers trained on gender and human rights', АмІऽом, 21 February $2017<$ http://amisom-au.org/so/2017/02/newly-deployed-military-officers -trained-on-gender-and-human-rights/>. 
and outreach, prevention, training, improved response mechanisms, remedial measures, formal accountability and reporting measures, and monitoring and evaluation. ${ }^{100}$ Conduct and discipline officers have been recruited to the AM ISOM mission. ${ }^{101}$ An Ам ISом Gender Unit has also been established, and has carried out SEA sensitization of senior officers in Mogadishu. ${ }^{102}$ The Gender Unit conducts gender sensitization, SEA training and outreach. ${ }^{103}$ The AU Peace and Security Department appointed a Gender Advisor in 2011, to oversee the better integration of gender considerations across its work, and the appointment of a Special Representative on Violence against Women and Children. ${ }^{104}$ The role was abolished in 2012 apparently however. ${ }^{105}$ AMISOM has also conducted outreach activities on SEA and training of IDP women on selfdefense. As correctly noted by HRW, much of their work appears reactionary, related to reputational concerns and offers only limited protection for victims faced with individuals with guns and authority. ${ }^{106}$ АM ISOM has established a Protection, Human Rights and Gender Cluster, which has engaged in training of focal point AMISOM personnel to the Human Rights Cluster in sensitizing them to IHL, IHRL and issues related to child protection, gender, SEA, AMISOM Rules of Engagement, Somali national human rights laws, and the AM ISOм во I policy and procedures. ${ }^{107}$ Similar training should be delivered more broadly to AMISOM personnel, and similar training needs to be developed for, and delivered across, AU peace operations beyond АMІІом more broadly.

There have been discussions on developing an AU level Conduct and Discipline Framework for AU Peace Support Operations, and draft policy documents are internally in circulation for further development. The Training for Peace Programme at ACCORD (TfP/ACCORD) and AU co-hosted an Expert

100 HRW Report, above n 37, AU Letter annex 3; See also, Irine Limo, The Training for Peace Program's Contribution to Gender Mainstreaming in Africa's Peace Operations, Conflcit Trends 2015/2, ACCORD (2015) <http://www.accord.org.za/conflict-trends/the-training -for-peace-programmes-contribution-to-gender-mainstreaming-in-africas-peace -operations/>.

101 cDiscussion <http://www.cdiscussion.com/me/cJobcontent.php?jobid=1021399 $>$.

102 HRW Report, above n 37, p. 49.

103 HRW Report, above n 37, p. 85, AU Letter annexed, p. 5 .

104 Abdullah, above n 20, p. 13.

105 Ibid., p. 14; Kasumba and Walter Lotze, above n 83, pp. 23, 27.

106 HRw Report, above n 37, p. 36.

107 амілом, Аміsом Officers Urged To Protect Vulnerable Groups During Military Operations (13 June 2016) <http://amisom-au.org/2016/o6/amisom-officers-urged-to-protect -vulnerable-groups-during-military-operations/>. 
Roundtable in the AU headquarters in Addis Ababa, Ethiopia in December 2014 to flesh out these documents. According to ACCORD these include:

a refined conduct and discipline directive on Psos; a refined draft Sexual Exploitation and Abuse (SEA) Policy; a refined draft "Whistle-blower"/ Protection/Retaliation Policy; a refined draft Annex to Memorandum of Understanding (MOU) on conduct and discipline and SEA specifically; recommendations for strengthening provisions of the AU Staff Rules and Regulations; and finally recommendations on use of Information, Communication and Technology (ICT) to support a conduct and discipline framework, including establishing a misconduct database tracking system. ${ }^{108}$

The finalized versions of these documents are not yet publically accessible for critique.

There is little solid information available about SEA or indeed other complaint mechanisms and procedures available with respect to AU operations, apart from occasional references to the existence of phone number, posters, emails and gender focal points. Reporting obligations on SEA allegations between mission and $\mathrm{HQ}$ level at the $\mathrm{AU}$ are unclear, and warrant clarification and transparency. ${ }^{109}$

It is astounding that the AU has not yet adopted a reformed SEA policy document at HQ level to govern all is operations. The Policy accessible is limited to AMISOM and appears largely reactionary in response to the scatting HRW report. The apparent lack of an adequate framework existing with respect to conduct and discipline issues on $\mathrm{AU}$ operations is specifically highlighted as a core regulatory area in need of address in a 2017 UN Report, which stipulates:

The African Union needs to put in place a conduct and discipline framework that sets out strategic, programmatic and operational expectations for all stakeholders - including the United Nations, the African Union and troop-and police-contributing countries. This framework would

\footnotetext{
108 ACCORD/TfP co-hosts experts' roundtable on developing a Conduct and Discipline Framework for the AU PSOs, 20 February 2015, ACCORD <http://trainingforpeace.org/news -items/accordtfp-co-hosts-experts-roundtable-on-developing-a-conduct-and-discipline -framework-for-the-au-psos/>; See also, Audit of the conduct and discipline function in the African Union-United Nations Hybrid Operation in Darfur, Internal Audit Division Report 2014/109, OiOs, Assignment No. AP2014/634/07 (29 September 2015).

$109 \quad$ HRW Report, above n 37, p. 53.
} 
include (a) standards that are equivalent to United Nations standards and are reflected in standard agreements with contributing countries and host country authorities, as appropriate; (b) monitoring mechanisms ... including systems to support monitoring activities, such as misconduct tracking databases; (c) compliance mechanisms to ensure preventative measures, including training ... vetting and awareness-raising; $(\mathrm{d})$ accountability measures to address cases of non-compliance, including but not limited to immediate removal and replacement of individuals reported to have violated conditions of service, sanctions in substantiated cases and criminal prosecution, as applicable, in the most serious cases such as those involving sexual exploitation and abuse; (e) remediation measures to address harm done to victims of violations of the standards of conduct, including sexual exploitation and abuse; and (f) reporting mechanisms to ensure transparency in matters of conduct and discipline. ${ }^{110}$

The AMISOM SEA Policy stipulates that personnel are required to 'report any concerns or suspicions they have regarding possible violations of this SEA Policy'.11 The AMIsom Policy refers the need to report incidents of SEA in 'good faith', yet there is no accompanying language as to how or by whom, and under what process such a determination is to be made. A draft Whistleblower was mentioned in the AU letter annexed to the $\mathrm{HRW}$ report. This was set to be reviewed at a June 2014 workshop but the final document has never been released. ${ }^{112}$ Moreover, the AU needs to adopt something akin to the UN's Whistleblower policy, set out in a UN SG Bulletin in 2005. ${ }^{13}$ That stated, the UN's Whistleblower policy has not been consistently well implemented at UN level, with the Kompass incident representing to many a disappointing illustration, reminiscent of cover-ups and retaliation in the past. ${ }^{114}$ So perhaps what is required is a determination to be made by some form of an independent body.

110 Report of the Secretary-General on options for authorization and support for African Union peace support operations, UN SCOR, UN Doc S/2017/454 (26 May 2017) [57].

111 Easy-to-Read Guide, above n 97, pp. 5, 9.

112 Work on this document during a working shop was noted, however, by ACCORD. ACCORD, above $\mathrm{n} 108$.

113 UN Ethics Office, Secretary-General's Bulletin on protection against retaliation, UN Doc ST/SGB/2005/21 (19 December 2005).

114 Jane Rasmussen, MONUC: Sexual Exploitation and Abuse. End of Assignment Report, United Nations Dрко, 25 February $2006<$ https://reliefweb.int/report/democratic-republic -congo/drc-monuc-sexual-exploitation-and-abuse-end-assignment-report >; Colum Lynch, 'The Whistleblower: The Movie the un would Prefer You Didn't See', Foreign Policy 
There is clearly a real need for a clear and strictly implemented Whistleblower protection policy and process within the AU. Witnesses and victims of SEA will otherwise be reluctant to report due to fear of physical injury, and employment-related or other reprisals.

The AMISOM SEA policy makes references to educating personnel and the public, but greater and routine emphasis ought to be placed on predeployment training of military personnel, in addition to in mission SGBV, SEA, cultural and gender training. Across AU operations this training should take into account contextual and environmental factors of the theatres to which AU personnel are deployed. Training at AM IsOM level was jointly organized by UNSOA/AMISOM from 2011 on, and has been conducted apparently in all sending states pre-deployment, with subsequent in mission refresher training on SEA. No mention is made of other AU missions.

AMISOM's letter responding to the HRW 2014 Report sets out existing mechanisms to address SEA as of 2014. These are for the most part non-specific. They state that the approach taken by AM ISOM is holistic, revolving around prevention, mitigation and punitive action. ${ }^{115}$ AMISOM highlighted its activities in relation to outreach and sensitization in Somalia on SEA. It mentions a Helpline it intended to establish attended by local Somalis that it intends to train on responding to SEA and offering counseling and support linkages. Otherwise reporting procedures are not articulated. The operation stresses the need to improve welfare and recreation facilities afforded to AMISOM personnel. This was also stressed in Prince Zeid's report in 2005 detailing a strategy to tackle SEA by UN peacekeepers. ${ }^{116}$

Within the AU system there is nothing akin to the UN Victim Assistance Strategy and Trust Fund. Moreover, there is little current ability to support victims in the pursuit paternity claims and engaging with the national authorities exercising jurisdiction over these peacekeepers. According to the AU it is working on a compensation policy for victims of SEA and SGBV, but there is little information available on any progress that has been made in this area. ${ }^{117} \mathrm{~A}$ strategy is apparently under development whereby it will fall under the PSOD

(29 June 2011) <http://foreignpolicy.com/2011/o6/29/the-whistleblower-the-movie-the-u -n-would-prefer-you-didnt-see/>.

115 See, Response to HRW 2014 Report, AU Doc AмIsом/ном/14/343.4 (19 October 2014) p. 3 $<$ http://www.peaceau.org/uploads/hrw.pdf >.

116 A Comprehensive Strategy to Eliminate Future Sexual Exploitation and Abuse in the United Nations Peacekeeping Operations, $59^{\text {th }}$ sess, Agenda Item 77, UN Doc A/59/710 (24 March 2005) [50]-[51] ('Zeid's Report').

117 See further, HRW Report, above n 37, AU Letter annex 3, p. 7 . 
at $\mathrm{AU} \mathrm{HQ}$ level to follow up complaints and compensation claims with troopcontributing states exercising jurisdiction over deployed personnel. That stated, efforts to provide any form of assistance to SEA victims in the context of UN peacekeeper babies and victim supports, including medical, has also had pretty mediocre progressions in this regard, albeit major changes appear underway over the past year, largely in response to the CAR allegations. ${ }^{118} \mathrm{Re}-$ formed process and structures must include a specific Victim Assistance Strategy, and focal points for the provision of such assistance. Assistance needs to be provided to SEA victims by the AU to better enable them to navigate foreign legal systems in the pursuit of paternity claims. States contributing troops to AU operations should be required to designate a national focal point who will be available to assist with the processing of paternity claims against its nationals, particularly military personnel, deployed to AU operations. Without such focal points victims are unlikely to be able to successful pursue any claims or indeed economic or social supports. What the AU mentions is the provision of "emergency assistance" for complainants. However, it does not specify what this entails nor does the AU identify exactly where the complainants should seek this assistance. ${ }^{119}$ Moreover, Post-Exposure Prophylaxis kits need to be made readily available at local medical facilities and hospitals in the area of peace operations. For instance, in Somalia, reporting of SG BV is highly stigmatized and can lead to serious negative repercussions or backlash for victims reporting such abuse, even possible prosecution. ${ }^{120}$ This is coupled with a lack of safe houses for victims, ${ }^{121}$ and far too few medical facilities to provide forensic medical examinations to officially document SGBV. ${ }^{122}$

With respect to SEA occurring at the hands of UN peacekeepers, the UN has established a new framework under the UN's Trust Fund for Assistance to Victims of Sexual Abuse and Exploitation. The un Trust Fund does not compensate victims, but is aimed at the provision of victim support structures, and medical and legal assistance. ${ }^{123}$ It now requires contributions from UN

118 See further, Special Measures for Protection from Sexual Exploitation and Abuse: A New Approach Report of the Secretary-General, un Doc A/71/818 (28 February 2017) [8].

119 Para 9 of Policy. Easy-to-Read Guide, above n 97.

120 See, Róisín Burke, 'Rule of Law Reform Initiatives: Impact on Gender Justice in Fragile, Conflict-affected States', Global Rule of Law Exchange Papers (Bingham Centre for the Rule of Law, June 2016) 4.

121 'Engaging communities in promoting women's rights, security and peace in South Central Somalia' (Seminar, CISP and International Alert, 30 October 2015).

122 Ibid.

123 Trust Fund for Victims of Sexual Exploitation and Abuse is Operational, un Conduct and Discipline Unit (24 January 2017) <https://conduct.unmissions.org/trust-fund-victims -sexual-exploitation-and-abuse-operational $>$. 
peacekeepers found to have engaged in SEA where substantiated, in accordance with GA Res $286 .{ }^{124}$ Moreover, it has requested the GA to concur with the withholding of 'reimbursement in the event that investigations are not undertaken, reported on and concluded in a timely manner, and to pay the amounts withheld into the Trust Fund.'125 Other measures have been proposed, such as withholding of accumulated annual leave and repatriation grants, in addition to placing individuals on administrative leave without pay until investigations are completed. ${ }^{126}$ Moreover, Member States are to be asked 'to consider procedures to withhold reimbursement payments' where investigations are nor taken in a timely manner. ${ }^{127}$ The UN SG, in 2017 , noted that amongst the revisions proposed, it intends to revise the terms of reference of the Trust Fund to 'permit direct assistance payments to include, for example, enabling victims to attend trials.' ${ }^{128}$ The GA is also requesting states contributing personnel to UN operations to 'receive claims from victims and the related establishment of mechanisms.' ${ }^{129}$ Moreover, the UN has requested states contributing personnel to its peace operations to appoint focal points for receipt of paternity claims against its peacekeeping personnel, and establish mechanisms to ensure that victims' claims are received. ${ }^{130}$ The UN is hiring a Victim's Rights Advocate, at the level of Assistant Secretary-General level, to assist victims in accessing appropriate legal procedures and other forms of assistance. This will include working in developing networks with local governments, and presumably troop-contributing states. ${ }^{131}$ At UN level a 2016 draft victims' assistance

124 GA Res 286, Un GAOR, $70^{\text {th }}$ sess, Agenda Item 116, Un Doc A/Res/286 (9 October 2006) [75].

125 Special Measures for Protection from Sexual Exploitation and Abuse: A New Approach Report of the Secretary-General, UN Doc A/71/818 (28 February 2017) pp. 26-27 and [34]-[35]; Special measures for protection from sexual exploitation and sexual abuse: Report of the Secretary-General, UN GAOR, $69^{\text {th }}$ sess, A/69/779 (2015) [76]; Special measures for protection from sexual exploitation and sexual abuse Report of the Secretary-General, UN GAOR, $79^{\text {th }}$ sess, Agenda Item 139, Un Doc A/70/729 (16 February 2016); GA Res 286, UN GAOR, $70^{\text {th }}$ sess, Agenda Item 116, UN Doc A/RES/286 (9 October 2006); UN GAOR, UN SCOR, $70^{\text {th }}$, sess, Agenda Items 56, 57 and 123, A/70/357-S/2015/682, (2 September 2015).

126 un Women, Preventing Conflict, Transforming Justice, Securing the Peace: A Global Study on the Implementation of United Nations Security Council resolution 1325 (October 2015) p. 117 .

127 Special measures for protection from sexual exploitation and abuse: a new approach Report of the Secretary-General, UN GOAR, UN Doc A/71/818 (28 February 2017) [34]-[35].

128 Ibid.

129 Ibid., p. 27.

130 Ibid., [34]-[35].

131 Ibid., [27]-[29]. 
protocol was developed and should now be in the pilot phase. ${ }^{132}$ The UN is developing a standardized incident reporting form, which should be in use by the end of 2017. The aim is 'to accelerate the provision of appropriate aid to victims' and to 'help to regularize the initiation of appropriate administrative and criminal investigations.' ${ }^{\text {133 }}$ Victims in the past have had little support in navigating or even accessing overseas legal systems to process their claims, including for child support. Similar issues will obviously arise with respect to AU peacekeepers, and ought to be similarly addressed.

A clear and dangerous gap in the AU's framework, if it can be called such, is the lack of specificity on how to make a complaint and to whom, and what the specific process will be thereafter. If something like this does exist, then it needs to be made easily and publically accessible to the local population and broader afield, including via clear articulation and contract points on the AU's website. This must be made easily accessible to local NGOS and civil society groups, and other key points of contact that victims of SEA are likely to turn to. ${ }^{134}$ Of course the latter will differ according to country context, and with respect to urban and rural areas. Assistance should also be established through establishing focal points at AU and sending levels to assist victims with processing their claims in overseas legal systems.

AMISOM has indicated that it intends to adopt a plan on SEA, and incorporate it as an Annex to its bi-lateral MOU with troop-contributing and policecontributing states. ${ }^{135}$ This would enhance the legal status of any policies and procedures devised to deal with SEA, making them binding on state parties. ${ }^{136}$ The proposed plan has not been released or, it appears, finalized. With respect to civilian personnel, pursuant to paragraph 55 of the Status of Mission

132 Ibid., [33].

133 Ibid., [41].

134 See further, Burke, 'Rule of Law Initiatives', above $\mathrm{n} 120$.

135 See further, The African Union releases the key findings and recommendations of the report of investigations on Sexual Exploitation and Abuse in Somalia, 21 April 2015, AU <http://www.peaceau.org/en/article/the-african-union-releases-the-key-findings-and -recommendations-of-the-report-of-investigations-on-sexual-exploitation-and-abuse-in -somalia>.

136 See, 2008 Manual on Policies and Procedures Concerning the Reimbursement and Control of Contingent-Owned Equipment of Troop/Police Contributors Participating in Peacekeeping Missions, $5^{\text {th }}$ Comm, $63^{\text {rd }}$ sess, Agenda Item 132, UN Doc A/C.5/63/18 (29 January 2009)

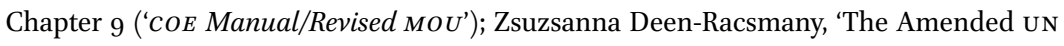
Model Memorandum of Understanding: A New incentive for States to Discipline and Prosecute Military Members of National Peacekeeping Contingents?' (2011) 16(2) Journal of Conflict and Security Law, p. 1. 
Agreement ('sOMA') AMISOM staff members are immune from local jurisdiction for civil allegations only, ${ }^{137}$ so in theory they can be investigated and prosecuted by Somali authorities for crimes committed in country. However, the majority of АМІ Ом personnel are military, and military personnel are subject to the exclusive criminal jurisdiction of the sending state. It is less clear what the status of police deployed under AMIsOM is but they likely are subject to sending state criminal jurisdiction. Article VI of the somA requires all AU personnel to respect local and international laws, including the Geneva Conventions of $1949 .{ }^{138}$

A repercussion of SEA by AU peacekeepers outlined in the AMISOM SEA policy refers to termination of employment: solely an administrative measure. There is no provision for support for those seeking some form of financial support or otherwise for children born out of SEA. Disciplinary and criminal sanctions are not mentioned in the document. Of course criminal and disciplinary procedures will in most incidences fall to the sending state, at least with respect to military personnel, albeit the individuals may be repatriated. ${ }^{139}$ The AU has no criminal jurisdiction over these personnel. With respect to an alleged 'gang rape' in 2013 AMISOM stated it set up а во but it states the NGO sheltering the victim would not allow access to the victim so that she could testify and that the investigation was subsequently taken over by the Federal Government of Somalia. ${ }^{140}$ HRW notes, however, that an AMISOM spokesperson interviewed observed that the allegation was declared unfounded by the вог despite not having interviewed the claimant or independent witnesses, rather it focused on interviewing AMISOM personnel and a camp logbook. ${ }^{141}$ This creates obvious risks of bias. It is not clear what has subsequently happened with this case. Moreover, it is not apparent how jurisdictional issues operated here, particularly in light of soma provisions on exclusive criminal jurisdiction over military personnel falling to the troop-contributing state. The allegations involved military personnel at a Ugandan troops' base in Mogadishu, yet the

137 See, Letter to HRW from the Special Representative of the Chairperson of the Commission (sRcc) for Somalia and Head of АмІSом, АU Dос АмІзом/ном/14/343.14 (19 October 2014) p. 5 .

138 Ibid.

139 Burke, Sexual Exploitation and Abuse: Moving Beyond, above $\mathrm{n}$ 1, Chs. 2 and 5 .

140 See, Letter to HRW from the Special Representative of the Chairperson of the Commission (sRcc) for Somalia and Head of АмISOM, AU Doc АмІзом/ном/14/343.14 (19 October 2014) p. 5 .

141 HRW Report, above n 37, p. 48. 
Somali government took over the investigation. ${ }^{142}$ This suggests that there is little clarity as to approach; and inconsistencies between documents, practice, monitoring and reporting on SEA allegations and the manner in which they are dealt with. Responses appear largely ad hoc. Further incidences of sexual violence and widespread civilian casualties at the hands of АM ISOM personnel are alleged to have occurred in 2016 and 2017 in a December 2017 UN report by the UN Human Rights and Protection Group (HRPG) of the UN SOM. ${ }^{143}$ AMISOM strongly denies the veracity of these claims and any inadequacy of its investigations into the alleged incidents. ${ }^{144}$ The claims had been received by UNSOM pursuant to the HRDDP monitoring framework and transmitted to AMISOM for follow-up and response to the UN on action taken. ${ }^{145}$

Reputational risk is one aspect of SEA, sexual abuse of civilians in the first instance could seriously undermine efforts to re-establish the rule of law and be used as propaganda by terrorist groups such as al-Shabaab. ${ }^{146}$ More broadly than peacekeepers, rape is rampant in Mogadishu, often perpetrated by men wearing military uniforms of a number of sources. ${ }^{147} \mathrm{UN}$ OCHA reported 'first six months of 2012, some 800 cases of sexual violence were reported in Mogadishu alone'. Of course this is in no way to suggest this is a broader АM Isom problem; the majority or incidents are likely local, but it demonstrates the extent of unlawfulness around sexual offences and vulnerability of the local population, lending to an environment where such crimes are perpetrated with relative

142 'Somalia gang rape victim accuses African Union force', Fox News (online), 20 August 2013 <http://www.foxnews.com/world/2013/o8/20/somalia-gang-rape-victim-accuses-african -union-force.html>.

143 Unsom and ohchr, Protection of Civilians: Building the Foundation for Peace, Security and Human Rights in Somalia (December 2017) [28],[31]-[32] <http://www.ohchr.org/ Documents/Countries/SO/ReportProtectionofCivilians.pdf>.

144 AU response letter - Annex to Unsom and онснR, Protection of Civilians: Building the Foundation for Peace, Security and Human Rights in Somalia (December 2017) p. 47.

145 On the HRDDP monitoring process regarding recent AMISOM SEA allegations, see further, unsom and онсhr, Protection of Civilians: Building the Foundation for Peace, Security and Human Rights in Somalia (December 2017) p. 7, fn 3 <http://www.ohchr.org/ Documents/Countries/SO/ReportProtectionofCivilians.pdf>.

146 'Somalia gang rape victim accuses African Union force', Fox News (online), 20 August 2013 $<$ http://www.foxnews.com/world/2013/o8/20/somalia-gang-rape-victim-accuses-african -union-force.html>.

147 Legal Action Worldwide (LAw), Legal Aid Providers Supporting Gender Based Violence Survivors in Somalia: Report and Recommendations (LAW, 2014) $32<\mathrm{http} / /$ legalaction worldwide.org/wp-content/uploads/2014/11/Legal-Aid-Providers-Supporting-Survivors -of-Gender-Based-Violence-in-Somalia- 2.pdf>. 
impunity. Moreover, victims reporting rape run the risk of prosecution and societal shaming. ${ }^{148}$ Therefore, there is little incentive to report.

The AU recommends the deployment by troop-contributing states of military courts where an SEA allegation arises in Somalia. At least one troopcontributing state already has deployed a military court on at least one occasion. ${ }^{149}$ The $\mathrm{AU}$ was to consult troop-contributing states regarding implementation of this recommendation, but little information is available on the outcome of these consultations. Considerable difficulties could arise, however, due to operational environments and security concerns, where conflict is still rife. ${ }^{150}$ This is likely an even greater concern for AU operations than those of the UN, as the AU tends to deploy to more volatile operational environments than the UN. Moreover, as noted by HRW, confidentiality of victims, and victims' safety in such unstable environments, would have to be assured and procedures and support structures put in place to ensure such. These might include in camera proceedings and relocation of victims where necessary. ${ }^{151}$

The AU released an 'Easy-to-Read Guide on Aміsом Policy on Prevention and Response to SEA'. In Annex 2 it rather vaguely comments on reporting and complaint mechanisms for SEA. ${ }^{152}$ A criminal investigation is not conducted, but rather any $\mathrm{AU}$ investigation or BOI is to ascertain whether exploitation or abuse has occurred. ${ }^{153}$ This is because the AU has no capacity to exercise criminal jurisdiction over its peacekeepers, as this rests with states. The Guide makes reference to the need to assess if protection of witnesses from intimidation is necessary, but there is no guidance on what protection measures might entail. 154 The need to ensure confidentiality is stressed. The Guide states that an investigative team should be appointment by senior management in the mission, and that the complainant be provided with a letter of confirmation

148 Fox News, above n 142.

149 unsom and онснr, Protection of Civilians: Building the Foundation for Peace, Security and Human Rights in Somalia (December 2017) [32] <http://www.ohchr.org/Documents/ Countries/SO/ReportProtectionofCivilians.pdf>.

150 Security causes significant problems for even carrying out domestic level prosecutions in Somalia by national authorities. 'Mobile Courts Workshop Opens in Mogadishu' (UNDP Somalia, 16 December 2015) <http://www.so.undp.org/content/somalia/en/home/press center/pressreleases/2015/12/16/joint-press-release-mobile-courts-workshop-opens-in -mogadishu.html>.

$15^{1} \quad$ HRW Report, above n 37, p. 59.

$15^{2}$ Easy-to-Read Guide, above n 97, Annex 2.

153 Ibid., Annex 2, [10].

154 See also, Special Measures for Protection from Sexual Exploitation and Abuse: A New Approach Report of the Secretary-General, un Doc A/71/818 (28 February 2017) [32]. 
of the complaint. ${ }^{155}$ It notes that investigations will be subject to varying legal constraints as to the extent of their authority, procedural rules, and provision of organizational policies and national employment and criminal laws, and employment contracts. Investigators need to be clear as to the substantive rules violated and their 'composite elements'. The Guide mentions the need to address the agency's Code of Conduct. Interestingly it acknowledges the AU's relationship with the UN and the UN'S SEA policy, in particular as set out in the SG's Bulletin on Special Measures for Protection from Sexual Exploitation and Abuse. It states '[i]f the agency is an implementing partner of the UN, those codes will generally incorporate all or part of the SG's Bulletin. In this case we will have to consider how the United Nations are affiliated to AM ISOM.'156

There is little concrete information publically available on solid complaints mechanisms for the victims of SEA. As noted, ${ }^{157}$ there appears to be nothing akin to the UN's OIOs, although one should bear in mind that oIOs has also been criticized for inadequacies in its dealings with SEA, including with respect to the CAR allegations discussed in Section I. Nevertheless, it is important to have a fully independent, adequately resourced, permanent body of investigators with expertise on SEA and criminal investigations rapidly deployable or in mission. Investigators need to have appropriate expertise in investigating SGBV, including with respect to children. ${ }^{158}$ These experts could be required to be certified by a body such as Justice Rapid Response. ${ }^{159}$ The AU noted in response to HRW's report, at least with respect to AMISOM, that '[n]o investigation capacity exists outside of the formed police units in the PSo which generally carry out investigations of minor violations....' It further highlighted that these investigators would have to be trained and reinforced with further investigative personnel if SEA is to be investigated. The AU has established BOIs, at least with respect to AMISOM, but presumably with respect to other AU operations, in the interim. ${ }^{160}$ AMISOM never publically released its full investigative report responding to the allegations raised in HRW's 2014 Report. It issued a press release summarizing the outcomes of its investigations and a series of recommendations. ${ }^{161}$ In SC Res 2182 the SC called on the AU to publicize

155 Easy-to-Read Guide, above n 97, Annex 2 [4], [6], [8].

156 Ibid., [12]; Secretary-General's Bulletin - Special Measures for the protection from sexual exploitation and sexual abuse, UN Doc ST/SG B/2003/13 (9 October 2003).

157 See, above p. 15 .

$15^{8}$ See, Paul Williams, 'Аміsом under Review' (2016) 161(1), International Peacekeeping, p. 46.

159 See, Justice Rapid Response <http://www.justicerapidresponse.org/>.

16o HRW Report, above n 37, p. 68, AU Letter annexed, p. 9.

161 See, Williams, Ам Isом under Review, above n 158, p. 46. 
the outcomes of these investigations and devise an SEA regulatory policy. ${ }^{162}$ Calls to finalize the AU's SEA and Conduct and Discipline policies were reiterated under the HRDDP framework in December 2017. Moreover, with respect to AMISOM the UN requested that misconduct mitigatory measures pursuant to the HRDDP be integrated into bi-lateral MOUs with personnel contributing states, in addition to 'the Rules of Engagement, АM Isом mission-specific Guidelines of the protection of civilians, Standards Operating Procedures relating to AMIso M's boards of inquiry, and various directives of the Special Representative of the Chairperson of the Commission and the Force Commander or Police Commissioner in the Mission.'163

There appears to be no database or tracking system within the AU's structures to record SEA, serious crimes and other human rights and IHL violations, akin to the UN's Misconduct Tracking System developed by the UN's Department of Field Support. This makes it difficult to assess the extent of the problem amongst troops and indeed AU civilian personnel, which lends to a lacks of transparency to the local population, their governments, victims, and the international community. The UN according to the SG's 2017 Report on SEA, stipulated that it will push Members States to support the establishment of 'a system-wide consolidated confidential repository of case information, to be placed under the supervision of the Special Coordinator on Improving the United Nations Response to Sexual Exploitation and Abuse, that will serve as the United Nations centralized repository of cases. The repository will build on the Misconduct Tracking System developed by the Department of Field Support.... ${ }^{164}$ A matrix of cases on SEA, IHL, IHRL and criminal offences by AU peacekeepers should be integrated alongside this tracking system, particular where support is to be offered by the UN to AU operations and where any rehatting is to occur. Indeed this would enable a more rapid re-hatting process and ease of transition from an AU operation to a UN operation. The UN SG in a February 2017 report notes that:

violations of international human rights and humanitarian law by nonUnited Nations international forces, including sexual violence, are usually monitored and reported on by the Office of the United Nations High

\footnotetext{
162 Res SC Res 2182, UnSCOR, $7286^{\text {th }} \mathrm{mtg}$, Un Doc s/Res/2182 (24 October 2014) [32].d.

163 Unsom and oнchr, Protection of Civilians: Building the Foundation for Peace, Security and Human Rights in Somalia (December 2017) pp. 30-31 <http://www.ohchr.org/Docu ments/Countries/SO/ReportProtectionofCivilians.pdf>.

164 Special Measures for Protection from Sexual Exploitation and Abuse: A New Approach Report of the Secretary-General, UN Doc A/71/818 (28 February 2017) [38].
} 
Commissioner for Human Rights, including human rights components of peace operations ... The Office does not have the mandate to carry out administrative or criminal investigations, which remains the prerogative of States. 165

The ability of the OHCHR to gather information on abuses depends on the level of their field presence, and access to sites of abuse and evidence. This in turn will require consideration of the capacity for protection of victims and OHCHR staff. There are little detailed procedures for follow-up and cooperation with respect to non-Un forces. ${ }^{166}$

AU Headquarters have a responsibility to put adequate procedures, structures, policy documents, administrative directives and practices in place to ensure an environment that is not conducive to sexual violence, exploitation, sexual transactions with beneficiaries of assistance, and impunity for sexual abuse. The AU has stated response letter to the HRW Report states that it will seek to mirror the UN in its approach to SEA zero-tolerance, but it fails to address the deeply flawed approach of the UN on the matter, at least until the recent push for further forms, and at least at the date of the letter. Improvements made to the AU regulatory system should also reflect on critiques of the UN's system to date and changes being proposed and implemented of the past year in responding to over two decades of allegations of SEA by UN peacekeepers. This was recognized also by the UN SG in his 2015 letter to the President of the SC. ${ }^{167}$

The Delegation of the EU to Somalia Human Rights Working Group recommends the establishment of an independent, permanent oversight body to monitor SEA allegations with respect to the $\mathrm{AU}$, in addition to an independent complaints mechanism in Mogadishu with respect to AMISOM personnel. The AMISOM SOMA provides that the mission shall ensure respect for IHL. ${ }^{168}$ The immunities set out under Sections 19 and 27 of the UN General Convention on Privileges and Immunities apply to senior АM ISOM personnel, akin to that of diplomatic envoys, which includes the Force Commander, Police Component

\footnotetext{
165 Ibid., [28].

166 Ibid., [29].

167 Letter dated 7 October 2015 from the Secretary-General addressed to the President of the Security Council, un Doc s/2015/762, (7 October 2015).

168 Status of Mission Agreement between the Transitional Government of the Somali Republic, and the African Union on the African Union Mission in Somalia, [9]-[10] <http://www .nuhanovicfoundation.org/user/file/2007_status_of_mission_agreement_between_soma lia_and_afric an_unioun.pdf_-_to_be_placed.pdf>.
} 
Commander, Head of Mission, and other high-ranking personnel as specifically agreed with the Government of Somalia. ${ }^{169}$ UN officials and UNVs remain governed by the Convention pursuant to Article V and VII. ${ }^{170}$ This means that they are immune from legal process for words spoken or written by them in the performance of their official duties. This immunity can be waived. This is similarly reflected in Article VI of the General Convention on the Privileges and Immunities of the Organisation of African Unity 1965 applicable to AU officials generally. ${ }^{171}$ Those specifically named as such serve as experts on mission, including military and civilians where notified by the Head of Mission to the Government. Pursuant to the agreement they are subject to the immunities set out in Article VI of the UN General Convention on Privileges and Immunities, which provides immunity from legal process i for words spoken and acts carried out in the course of their mission. ${ }^{172}$ This is reflected in Article VII of the General Convention on the Privileges and Immunities of the Organisation of African Unity. ${ }^{173}$ Military contingent personnel are subject to the exclusive criminal jurisdiction of their sending under Article 55(b). With respect to civilian AMIOSM personnel acting outside official duties, it may be agreed with the Head of Mission that the Somali Government may commence criminal proceedings pursuant to Article 55(a).

Privileges and immunities with respect to the AU-UN hybrid UNAMID mission in Darfur incorporate the standards on immunities set out in the UN's Convention on Privileges and Immunities, pursuant to the tri-lateral soma. Moreover, per the SOMA, 'UNAMID and its members shall respect relevant rules and principles of international law, including $\mathrm{IHL}$, as well as all local laws and regulations.' Ensuring this observance falls under the responsibility of the Joint AU/UN Special Representative for UNAMID. ${ }^{174}$ Per paragraph 50 of the

\footnotetext{
169 Ibid., [25].

170 Ibid., [26].

171 Article vi, General Convention on the Privileges and Immunities of the Organisation of African Unity, opened for signature 25 October 1965, 1000 UNTS 393 (entered into force 25 October 1965).

172 Status of Mission Agreement between the Transitional Government of the Somali Republic, and the African Union on the African Union Mission in Somalia, [27] <http://amisom-au .org/wp-content/uploads/2011/og/Status-of-Mission-Agreement-on-AMISOM.pdf>.

173 Article VII (1)(b), General Convention on the Privileges and Immunities of the Organisation of African Unity, opened for signature 25 October 1965, 1000 UNTS 393 (entered into force 25 October 1965).

174 Agreement between the United Nations and the African Union and Sudan concerning the Status of the African Union/United Nations Hybrid Operation in Darfur, Treaty Series 2503: Treaties and International Agreements Registered or Filed and Recorded with the
} 
tri-lateral Agreement jurisdictional immunity from host State laws is provided to all UNAMID personnel for acts carried out in their official capacity. No mention is made of a broader immunity for criminal acts falling outside their official functions with respect to civilian personnel (including civilian members of the military component), under which sexual offences will obviously fall. This means these acts could feasibly come within the criminal jurisdiction of the host State, where agreed by the Joint Special Representative. According to the SOMA, trial of any civilian personnel must be 'in accordance with international standards of justice, fairness and due process of law, as set out in the International Covenant on Civil and Political Rights. ${ }^{.175}$ However, military personnel fall under the exclusive criminal jurisdictional of the troop-contributing state, per para $51(b)$ of the somA. ${ }^{176}$

\section{Immunities of Staff and Officials}

Apart from the above mentioned documents, AU 'staff', a category under which the majority of military peacekeepers will not fall, are subject to AU 'draft' Staff Rules and Regulations. Pursuant to these Rules and Regulations, albeit in draft form, AU staff 'have the immunities set out under the OAU General Convention on Privileges and Immunities; Headquarters and Host Agreements; and such other Agreements that may be concluded by the Union and host countries, bar local staff.' But this immunity can be waived, pursuant to rule 7.2. Elected officials are provided with diplomatic immunities. According to Regulation 12, a Disciplinary Board advises 'on disciplinary offences and misconduct committed by these staff, which may include administrative measures, up to and including dismissal'. Decisions can be appealed to the Chairperson of the compotent organ, and subsequently to the AU's Administrative Tribunal. Final appeal is permissible to the African Court of Justice and Human Rights. ${ }^{177}$

\section{AMISOM SEA Policy Terms on SEA}

As noted, AM ISOM formulated a policy on Prevention and Response to Sexual Exploitation and Abuse in Sept 2013, which is in line with the UN's zero tolerance policy. ${ }^{178}$ The Policy is a guidance document, without any binding legal

Secretariat of the United Nations, No. 44760. African Union, Sudan and United Nations [5] $<$ http://dx.doi.org/10.18356/od238ffi-en-fr >.

175 Ibid., [51](a).

176 Ibid.

177 Assembly of the Union, Fifteenth Ordinary Session. 'Draft African Union Staff Regulations and Rules.' Assembly/AU/4(Xv). 25-27 July $2010<$ http://www.aucareers.org/Docs/ English\%2oSRR.pdf>.

178 Easy-to-Read Guide, above n $97 \mathrm{~s}$. 
effect. It does not yet appear to have been annexed to Mous with states contributing police or troops, as has occurred in the case of UN peace operations since revisions to its Model MOU in 2007. ${ }^{179}$ The policy document covers uniformed and non-uniformed AMISOM personnel. SEA is also prohibited by the AU Commission's Reviewed Code of Conduct ('AUC Code of Conduct'). The Code forms a part of pre-deployment trainings. It is annexed to AMISOM's SEA policy and is applicable to uniformed and ununiformed AU personnel..$^{180}$

It is bizarre, and perhaps reactionary, that such a document was formulated solely to cover AMISOM and not AU peace operations more generally. The Policy prohibits 'sexual activity with children'. A child under the policy is anyone under the age of 18 , irrespective of any other categorization of a child under local laws. It not a defence that a perpetrator operate under a 'mistaken belief in the age of a child.' The Annexed Auc Code of Conduct refers to the need to behave in 'a manner befitting the dignity of discipline, caring, considered, mature respected and trusted personnel displaying the highest integrity and impartiality ... and do not abuse or misuse your position of authority'.181 Peacekeepers per the Code are not to 'indulge in acts of sexual, physical or psychological abuse or exploitation of the local population'182 or '[a]ny exchange of money, employment, goods or services for sex'; '[a]ny type of sexual activities with children'; '[a]ny form of humiliation, degrading or exploitive behavior'; '[a]ny sexual favor in exchange for assistance'; '[a]ny type of sexual misconduct that damages the image, credibility, impartiality or integrity of the force'; in addition to sexual exploitation of subordinates. ${ }^{183}$ This includes the engagement of services of sex workers irrespective of local laws. The Policy and Code of Conduct largely reflect the UN Secretary General's Bulletin on Special Measures for Protection from Sexual exploitation and Abuse. ${ }^{184}$ Sexual

179 Report of the Group of Legal Experts on making the standards contained in the SecretaryGeneral's bulletin binding on contingent members and standardizing the norms of conduct so that they are applicable to all categories of peacekeeping personnel, UN GAOR, $61^{\text {st }}$ sess, Agenda Item 33, Un Doc A/61/645 (18 December 2006). These mous remain confidential to the AU.

180 African Union Commission, Implementation of the Women Peace and Security Agenda in Africa (Office of the Special Envoy on Women, Peace and Security of the Chairperson of the African Union Commission, Ethiopia, 2016) p. $35<$ http://www.un.org/en/africa/osaa/ pdf/pubs/2016womenpeacesecurity-auc.pdf>.

181 Easy-to-Read Guide, above n 97, Annex 1, African Union Commission (AUC) Reviewed Code of Conduct, [1].

182 Ibid., [4].

183 Ibid., [5].

184 UN Ethics Office, Secretary-General's Bulletin on protection against retaliation, UN Doc $\mathrm{ST} / \mathrm{SGB} / 2005 / 21$ (19 December 2005). 
relationships between AMISOM personnel and beneficiaries of assistance are discouraged under the Policy due to inherently unequal power dynamics', which the Policy links to undermining the AU's credibility and integrity. Where such relationships arise they must be disclosed to a supervisor. ${ }^{185}$ The policy prohibits personnel from partaking in 'any form of sexual exploitative or abusive activities, including, for example, child pornography or trafficking of human beings. ${ }^{186}$ Finally reference is made in the annexed Code of Conduct to the need for peacekeeping personnel to 'respect the law of the land of the host country'. 187 The Policy stipulates that SEA by AMISOM personnel constitutes a form of 'gross misconduct and are therefore grounds for termination of employment.'188 It would appear that with respect to military personnel this would merely requite the administrative measure of repatriation and termination of deployment with AM ISOM.

The policy refers to AMISOM's commitment to establishing an improved framework to prevent and respond to SEA, establishing complaint mechanisms for reporting SEA, and to incorporate its standards on SEA into induction and training courses for AMISOM personnel. Moreover, it commits to the use of interview techniques appropriate for dealing with witnesses and victims of SEA, particularly children. It also commits to the provisions of basic emergency medical and legal assistance 'as appropriate and feasible' to SEA complainants. ${ }^{189}$ At present these are merely guiding principles with minimal implementation. There is no definition as to what constitutes 'sexual abuse' and 'sexual exploitation' but presumably the terms are intended to reflect the wording used in the UN SG's 2003 Bulletin on Special Measures for Protection from SEA ('SG 2003 Bulletin'). ${ }^{190}$ The sG's Bulletin has been widely criticized for being inadequate in terms of stratifying the conduct to better reflect national criminal laws, and ultimately enable criminal investigations and prosecution where warranted for serious offences, and disciplinary action for conduct falling on the lower end of the scale. Moreover, it is unclear whether sexual relationships are necessarily prohibited. Vague terminology undermines the potential for impact. The issue of agency of local women and girls in the context of survival sex or even

185 Easy-to-Read Guide, above n 97, Annex 1, African Union Commission (AUC) Reviewed Code of Conduct, [3].

186 Ibid., Annex 1, African Union Commission (AUC) Reviewed Code of Conduct, [5].

187 Ibid., [2].

188 Ibid., p. 5 .

189 Ibid., pp. 6-7.

190 UN Ethics Office, Secretary-General's Bulletin on protection against retaliation, UN Doc $\mathrm{ST} / \mathrm{SGB} / 2005 / 21$ (19 December 2005). 
ordinary relationships is not adequately factored in and the policy appears over inclusive regard the scope of sexual conduct referred to, yet also weak in terms of specificity of conduct. ${ }^{191}$ The UN SG's 2003 Bulletin and the UN's Ten Rules: Code of Personal Conduct for Blue Helmets and We Are United Nations Peacekeepers, ${ }^{192}$ also suffer from similar weaknesses. Academic, civil society, UN, and practitioner have criticized the UN SEA policy documents, calling for a reform of the UN SG 2003 Bulletin. ${ }^{193}$ A parallel policy document therefore will not adequately fill gaps and the AU policy's terminology appears even more non-specific. At UN level there have been efforts to streamline the terminology used to report SEA allegations system-wide, with the production of a UN Glossary of Terms related to SEA, as a reference tool without legal effect. ${ }^{194}$ However, terminology also needs to be further defined and stratified to better reflect national criminal laws, perhaps set out in a Convention. ${ }^{195}$ With respect to UN peacekeepers, a Draft Convention, which was proposed by a Group of Legal Experts mandated to look at options for better addressing deal with sexual offences and other serious crimes by UN officials and experts on mission, is still

191 For a discussion of agency in this context see further, Olivera Simic, 'Rethinking "sexual exploitation" in UN peacekeeping operations' (2009) 32(4) Women's Studies International Forum, pp. 288-295; Dianne Otto, 'Making Sense of Zero- Tolerance Policies in Peacekeeping Economies' in Vanessa Monro and Carl Stychin (eds), Sexuality and the Law: Feminist Engagements (2007) pp. 267-270; Paul Higate, 'Gender and Peacekeeping Case Studies: The DRC and Sierra Leone', Iss Monograph No. 91 (Institute for Security Studies, Pretoria, March 2004) pp. 22-23, 43-44.

192 UN Department of Peacekeeping Operations, Ten Rules: Code of Personal Conduct for Blue Helmets <www.un.org/en/peacekeeping/documents/ten_in.pdf>; uN Department of Peacekeeping Operations, We Are United Nations Peacekeepers <www.un.org/en/ peacekeeping/documents/un_in.pdf >.

193 See further, Burke, Sexual Exploitation and Abuse: Moving Beyond, above n 1, pp. 29-32.

194 United Nations, un Glossary of Terms, above n 9.

195 See draft Convention, at: Ensuring the Accountability of United Nations Staff and Experts on Mission with Respect to Criminal Acts Committed in Peacekeeping Operations - Report of the Group of Legal Experts, UN GAOR, 6o ${ }^{\text {th }}$ sess, Agenda Item 32, UN Doc A/6o/980 (16 August 2006); See further, O'Brien, Melanie, 'Issues of the Draft Convention on Criminal Accountability of United Nations Officials and Experts on Mission', in Quénivet, Noëlle and Shah-Davis, Shilan (eds), International Law and Armed Conflict Challenges in the $21^{\text {st }}$ Century (T.M.C. Asser Press, 2010) p. 57; Zsuzsanna Deen-Racsmany, 'The Amended uN Model Memorandum of Understanding: A New incentive for States to Discipline and Prosecute Military Members of National Peacekeeping Contingents?' (2011) 16(2) Journal of Conflict and Security Law, pp. 1, 32-34. 
under discussion at the UN. ${ }^{196}$ Equally with respect to SEA by AU peacekeepers, if such a Convention was drawn up, it might assist in determining what types of offences should be covered reflecting their seriousness.

III

\section{Un's Due Diligence Policy for Non-United Nations Security Forces $^{197}$}

In June 2015 the High-Level Independent Panel on Peace Operations called on the UN to strengthen its partnerships with regional organizations, such as the AU and EU, in conducting peace operations. ${ }^{198}$ Partnerships between the UN and national, regional and multinational forces, akin to those touched on in the above scenarios are increasingly likely to be part of a complex web by which peacekeeping and peace-building are conducted. These operations often occur in parallel with UN political missions and operate with varying levels of support by the UN, EU and others. They are also often sequenced, wherein they commence as a regional operation in a particularly volatile situation, as occurred with the AU in Somalia, and transition into a UN peace operation through a process of re-hatting of troops. These partnerships will likely build on experiences of tri-lateral partnerships between the $\mathrm{UN}, \mathrm{AU}$ and the $\mathrm{EU}$, in CAR, Mali and Somalia over recent years. ${ }^{199}$ Indeed, areas of collaboration between the AU and UN, discussed at a March 2016 meeting of the UN-AU Joint

196 Report of the Group of Legal Experts on ensuring the accountability of United Nations staff and experts on mission with respect to criminal acts committed in peacekeeping operations, UN GAOR, $60^{\text {th }}$ sess, Agenda Item 32, UN Doc A/6o/980 (2006) pp. 17-19.

197 HRDDP, UN GAOR, Un SCOR, $67^{\text {th }}$ sess, Un Doc A/67/775-S/2013/110 (5 March 2013) Annex, Human Rights Due Diligence Policy on United Nations Support to Non-United Nations Security Forces; Statement by the President of the Security Council, un Doc S/PRST/2014/3 (12 February 2014) pp. 17-18, 27-28; Helmut Philipp Aust, "The Un Human Rights Due Diligence Policy: An Effective Mechanism against Complicity of Peacekeeping Forces' (2015) 20 Journal of Conflict and Security Law, pp. 61-73.

198 Report of the High-level Independent Panel on Peace Operations on uniting our strengths for peace: politics, partnership and people, UN GAOR, UN SCOR, $70^{\text {th }}$ sess, UN Doc A/70/95, s/2015/446 (17 June 2015).

199 See further, Walter Lotze and Tobias Pietz, 'Trilateral Cooperation in Peace Operations: Strengthening AU, UN and EU Cooperation in Africa, Federal Foreign Office', Centre for International Peace Operations, and UN-AU-EU Partnerships in Crisis Management and Peace Operations (2015) <http://www.zif-berlin.org/fileadmin/uploads/ueber_zif/doku mente/ZIF_background_paper_trilateral_cooporation_261015.pdf $>$; Regarding AU, UN, EU partnerships, see: Secretary-General's Remarks: Security Council Open Debate on "United Nations Peacekeeping: Regional Partnership and its Evolution", United Nations 
Task Force, include Burundi, Libya, Mali/Sahel, Somalia, South Sudan, and Western Sahara. ${ }^{200}$ The UN has also undertaken hybrid missions with the AU, such as UNAMID. ${ }^{201}$ UNAMID was fully funded by UN assessed contributions.

The UN has provided logistical support to AU missions, including through UNSOA and the establishment of a Trust Fund. ${ }^{202}$ Indeed, in articulating a preference for AU-led peace operations to be primarily funded through the UN's regular assessed contributions, the AU states that 'the UNSC retains the primacy for the maintenance of international peace and security and that, in undertaking peace operations in the continent, the $\mathrm{AU}$ is responding to an international obligations and acting on behalf of the Un.'203 Article $17(1)$ of the Protocol relating to the Establishment of the Peace and Security Council ('PSC Protocol'), stipulates that Chapter VIII of the UN Charter is the basis for its relationship and cooperation with the UN SC. It again acknowledges that the SC remains the primary international actor responsible for international peace and security. Article 17(2) of the PSC Protocol stipulates that:

Where necessary, recourse will be made to the United Nations to provide the necessary financial, logistical and military support for the African Union's activities in the promotion and maintenance of peace, security

(28 July 2014) <https://www.un.org/sg/en/content/sg/statement/2014-07-28/secretary -generals-remarks-security-council-open-debate-united $>$.

Note to Correspondents: United Nations-African Union Joint Task Force on Peace and Security Holds Twelfth Consultative Meeting in New York (22 March 2016).

201 Agreement between the United Nations and the African Union and the Government of Sudan concerning the status of the African Union/United Nations Hybrid operation in Darfur, (9 February 2008); Security Council recently renewed the mandate of the African UnionUnited Nations Hybrid Operation in Darfur (UNAMID) until 30 June 2018, Security Council Renews Mandate of African Union-United Nations Hybrid Operation in Darfur, Unanimously Adopting Resolution 2363 (2017), United Nations (29 June 2017) <http://www.un.org/ press/en/2017/sc12893.doc.htm>.

202 See, Report on Predictable and Sustainable Financing for Peace in Africa, AU (August 2016) [26] <http://www.peaceau.org/en/article/report-on-predictable-and-sustainable -financing-for-peace-in-africa $>$.

203 Common African Position on the AU Review of Peace Operations, AU Peace and Security Council, 202 ${ }^{\text {nd }} \mathrm{mtg}$, AU Doc PSC/PR/2(DII) (29 April 2015) p. 10; See also, Report of the African Union-United Nations Panel on Modalities for Support to African Union Peacekeeping Operations, Identical letters dated 24 December 2008 from the Secretary-General addressed to the President of the General Assembly and the President of the Security Council, $63^{\text {rd }}$ sess, Agenda Item 31, UN Doc A/63/666-S /2008/813 (31 December 2008) ('Prodi Report'). 
and stability in Africa, in keeping with the provisions of Chapter VIII of the UN Charter. ${ }^{204}$

UN supports range from the provision of significant funding to AU peace operations (with the AU committing to $25 \%$ of self-funding of its operations), ${ }^{205}$ logistical supports, technical and planning expertise, including with respect to 'conflict prevention, mediation, military and policy planning, financial and logistics management, SSR, DDR and mine action.'206

These relationships between the $\mathrm{UN}, \mathrm{AU}$ and other regional and multilateral bodies, and the transition between these various types of operations, creates complications in terms of applicable standards, vetting for human rights abuses and sexual violence or exploitation; re-hatting; ${ }^{207}$ due diligence policy implications; and policy, ethics and legality dilemmas this causes. Moreover, this likely results in confusion for those transitioning from one form of peace operation to another in terms of the regulatory frameworks applicable. Of course, one cannot view this in a vacuum, with often the dire need for urgent deployments of troops. Varied levels of relationships between UN and nonUN actors, such as the AU, give rise to complex issues with respect to the law of international organization responsibility; conflicting and/or weak regulatory and institutional frameworks; and respect for international humanitarian law, international human rights law, refugee law, and, here, zero-tolerance of sexually abusive conduct by peacekeepers. As noted, in 2013 the UN SG formulated the Human Rights Due Diligence Policy on UN support to non-UN security forces ('HRDDP'). ${ }^{208}$ The HRDDP policy governs situations where the UN is lending support state and non-state actors beyond the remit of the UN, often, with various levels of support and inter-connections. It aims to prevent the UN from supporting these actors where that support is inadvertently used for the commission of grave violations of international humanitarian law, refugee law,

204 Common African Position on the AU Review of Peace Operations, AU Peace and Security Council, 202 ${ }^{\text {nd }} \mathrm{mtg}$, AU Doc PSC/PR/2(DII) (29 April 2015); Prodi Report, $63^{\text {rd }}$ sess, Agenda Item 31, Un Doc A/63/666-s/2008/813 (31 December 2008).

205 See, e.g., Report of the High-level Independent Panel on Peace Operations on uniting our strengths for peace: politics, partnership and people, UN GAOR, UN SCOR, $70^{\text {th }}$ Sess, UN Doc A/7o/95, s/2015/446 (17 June 2015) pp. 20-21.

206 Ibid., p. 21.

207 The UN GA alludes to problems caused by re-hatting of troops. GA Res 286 , UN GAOR, $70^{\text {th }}$ sess, Agenda Item 116, Un Doc A/RES/286 (9 October 2006).

208 HRDdP, Un GAOR, Un SCOR, $67^{\text {th }}$ sess, Un Doc A $/ 67 / 775$-s/2013/110 (5 March 2013) Annex, Human Rights Due Diligence Policy on United Nations Support to Non-United Nations Security Forces. 
and/or human rights. The HRDDP stipulates that support by the UN for non-UN security forces must be in line with the UN Charter, and the principles underlying the Charter, which include the need to 'respect, promote and encourage respect for international humanitarian law, human rights and refugee law.'209 It is not too far a stretch to see how the HRDDP is partly a procedure for shielding the UN from responsibility for violations of international law. The wording of the policy leaves significant gaps in meeting those responsibilities, and even more so where proper implementation of the HRDDP is lacking. Nevertheless the HRDDP can, where properly implemented, go towards evidence of the exercise of due diligence in ensuring adherence to core international obligations under IHRL, IHL and refugee law (insofar as these place obligations on the $\mathrm{UN}) .210$

It is worth bearing in mind, at least at present, the UN's ability to examine complaints of SEA by forces operating outside UN command, is not from a disciplinary perspective, but rather focuses on the issue from the perspective of possible human rights violations. As Karomba notes when it comes to rights violations (here SEA) there is a 'need for merger of procedural approaches'.211

The HRDDP stipulates that it will terminate support of non-UN forces 'where continued support would implicate the Organization in grave violations of international humanitarian, human rights and refuges law'.212 The difficulty with this terminology is that it tends to undermine the broader remit of the policy, incorporating only 'grave' violations. There is little guidance on what constitutes 'grave violations', but the policy indicates that the threshold for such, in line with the Rome Statute for the ICC, is high, and likely unreasonably so. It specifically stipulates that 'grave violations' include: "crimes against humanity', as defined in the Rome Statute of the International Criminal Court, or 'gross violations' of human rights, including summary executions and extrajudicial killings, acts of torture, enforced disappearances, enslavement, rape

\section{Ibid.}

210 Burke, Sexual Exploitation and Abuse: Moving Beyond, above n 1, Ch. 3; Jérémie Labbé and Arthur Boutellis, 'Peace Operations by Proxy: Implications for Humanitarian Action of UN Peacekeeping Partnerships with Non-un Security Forces' (2013) 95 International Review of the Red Cross, pp. 539-559.

211 Watson Karuma Karomba, 'Sexual Exploitation and Abuse (SEA) in Peacekeeping: Case of the Central African Republic' (2016) 4, International Peace Support Training Centre Issue Brief, p. $49<$ http://www.ipstc.org/media/documents/Issue_Briefs_No6_Nov_2016.pdf>.

212 HRDDP, UN GAOR, UN SCOR, $67^{\text {th }}$ sess, UN Doc A $/ 67 / 775$-S/2013/110 (5 March 2013) Annex, Human Rights Due Diligence Policy on United Nations Support to Non-United Nations Security Forces [28]. 
and sexual violence of a comparable serious nature."213 There must be 'substantial' grounds to believe that there is a real risk of these forms of breaches of international law, under the terms of the policy. The meaning of the term 'substantial' is not defined in the Policy and leaves a lot of room for discretion on the part of the UN.

Nevertheless, as the ICRC notes, the HRDDP framework does enable the UN to engage proactively and influence the behaviors of non-UN security forces it engages with and supports with respect to respect for human rights, IHL and refugee law. Indeed the language contained in the policy includes an obligation to 'intercede with the relevant authorities' where substantial grounds arise to believe that these non-UN security forces are committing 'grave violations' of human rights or IHL. Nevertheless, this can only be done with substantive and consistence adherence to and implementation of the policy. The proper implementation of the policy would assist in the UN's own adherence to its international law obligations where complicity could otherwise pose a real conundrum. ${ }^{214}$ But the HRDDP is also more nuanced than this. The wording indicates that even if there is a risk of violations the UN must ask that body or state to desist from this conduct and, failing their doing so support must be withdrawn.

A Review Group established by the UN SG, and co-chaired by OHCHR and DPKO oversees implementation of the HRDDP. The Review Group also includes, OLA, OCHA, UNODC, DPA, UNICEF, SRSG-CAAC, DOCO, and PBSO. ${ }^{215}$ Curiously, UN Women have not been specifically included. The HRDDP has been integrated by the UN SC into peace operation mandates. The OHCHR maintains a human rights database with respect to human rights violations by peacekeepers, which should include incidents of SGBV. However, there are indications that that this database has not been consistently utilized, as highlighted by the CAR Panel, based on its interviews. ${ }^{216}$

There are linkages between adequacy of vetting processes both within the AU if seeking UN supports, but also in the re-hatting process and implementation of the HRDDP. The UN needs to see how ensuring adequate vetting can be institutionalized and integrated within the HRDDP process. Indeed the UN Guidance document on the implementation of the HRDDP, stipulates that ' $[\mathrm{f}]$ or support to regional peacekeeping forces, the UN entity will look into the

\footnotetext{
213 Ibid.

214 See further, Aust, above $\mathrm{n} 197$.

215 OHCHR < www.ohchr.org/Documents/Vacancies/2015/va15092.doc >.

216 CAR Panel Report, above n 2, p. 94.
} 
record of security forces of each Troop Contributing Country.'217 This includes the State's human rights and accountability records. The Guidance note states the UN will assess:

The record of the recipient(s) in taking or failing to take effective steps and corrective measures to hold perpetrators of any such violations accountable, both generally and for specific cases of violations. The effective nature of the "steps" should be assessed on the basis of relevant international human rights standards (for example, a mere disciplinary procedure is not adequate for an act of torture $)^{218}$

It goes on state that the UN will look at preventative measures, in line with para 14(c) of the HRDDP including whether:

any corrective measures or mechanisms have been taken or institutions, protocols or procedures put in place with a view to preventing the recurrence of such violations and, if so, their adequacy, including institutions to hold any future perpetrators accountable.

So the UN should look at corrective measures within the AU system and assess them for effectiveness. If risks or IHL and IHRL abuses are considered of medium level, mitigation measures are to be requested of the entity receiving support. ${ }^{219}$ With respect to the AU, these could include, under the guidance of the UN, measures to better deal with SEA by AU peacekeepers should it arise. Moreover, the UN might request the exclusion of particular units or contingents with a high incident rate of SEA, which remains inadequately addressed. Moreover, in exchange for support the UN could request the AU to develop regulations or policies in line with that of the UN on SEA in their most recent forms. ${ }^{220}$ Indeed, this is already occurring to an extent under the HRDDP in relation to AMISOM where an AU-UN AMISOM Joint Working Group on HRRDP has been established, and may provide a testing ground for how this might

217 HRDDP, UN GAOR, Un SCOR, $67^{\text {th }}$ sess, Un Doc A/67/775-s/2013/110 (5 March 2013) Annex, Human Rights Due Diligence Policy on United Nations Support to Non-United Nations Security Forces, p. 20.

218 Ibid., [14](b).

219 Human Rights Due Diligence Policy on UN Support to Non-UN Security Forces: Guidance Note, pp. 24, 27 <http://southsudanhumanitarianproject.com/wp-content/uploads/sites/ 21/formidable/2014.07.01.Revised-HRDDP-GN.pdf>.

$220 \quad$ Ibid., 31. 
operate. ${ }^{221}$ Moreover, there is a need for greater reflection on how this links to subsequent re-hatting processes and operation transition benchmarks. This has broader implications across UN operations. With respect to the AMISOM operation the SG has stated that he:

strongly support the establishment of a dedicated capacity for conduct and discipline in UNSOA to support UNSOA and UNSOM and to advise the African Union and Амізом on the development and implementation of its zero-tolerance policy. This is especially important as the Organization's own policy and implementation mechanisms continue to evolve with the approval by the General Assembly of special measures to strengthen the United Nations response to sexual exploitation and abuse. $^{222}$

AMISOM does not appear to have a clear vetting system in place with respect to personnel deploying under its umbrella. This needs to be rectified within the AU regulatory framework, perhaps under the authority and monitoring of the AU PSOD, coupled with a misconduct database tracking system that is accessible to the UN when supporting AU operations or when re-hatting. The tracking system might adopt the same or similar methodology to the UN's Misconduct Tracking System. ${ }^{223}$ There are, at present, no clear statistics on the prevalence of SEA in AU operations. According to the AU in its letter annexed to the $2014 \mathrm{HRW}$ report it has plans to establish such a database with UN assistance. ${ }^{24}$ It is not apparent what progress has been made on this and whether the AU intends this to apply across AU peace operations. Moreover, it does not expand on whether, and how, information will be transferred to bodies such as the UN. Moreover, it is not clear whether records of human rights abuses and other serious criminal offences, including sexual offences, committed at home

221 Unsom and oHCHr, Protection of Civilians: Building the Foundation for Peace, Security and Human Rights in Somalia (December 2017) [33]<http://www.ohchr.org/Documents/ Countries/SO/ReportProtectionofCivilians.pdf>.

222 Letter dated 7 October 2015 from the Secretary-General addressed to the President of the Security Council, Un Doc s/2015/762 (7 October 2015) [97].

223 Note that Ам гом established a Civilian Casualty Tracking, Analysis and Response Cell (CCTARC) to record abuses by АмISOм personnel but it reportedly is not functional. Report of the Secretary-General on Somalia, un Doc s/2011/759 (9 December 2011) [69]; SC Res 2182, UN SCOR, 7286 $6^{\text {th }}$, UN Doc S/RES/2182 (24 October 2014); Legal Action Worldwide, Legal Responsibility and Accountability, above n 53; SC Res 2036, UN SCOR, 6829 $9^{\text {th }}$ mtg, UN Doc s/REs/2093 (6 March 2013) [11].

224 HRW Report, above n 37, Letter Annex 3, p. 6. 
or elsewhere by personnel being considered for deployment will be included. It is also not apparent whether the measures taken at present in АM ISOM, or other AU operations, are adequate to decipher whether SEA has taken place. Of course, an individual should not be punished for an unproven or disproved allegation. A database system of prior misconduct and certification of past compliance with IHL and IHRL, including with respect to sexual crimes needs to be established and fed into the UN database. Sc Res 2182 encourages AMIsOM to establish such 'a centralized database for the efficient and independent receipt, preliminary assessment and tracking of investigations into allegations of sexual and gender- based violence and sexual exploitation and abuse, including through the institution of protective measure for complainants in order to prevent the redeployment'. ${ }^{225}$ Troop-contributing states are integral to the vetting process and are relied on by the AU. ${ }^{226}$ Akin to the process with regards to UN peacekeepers, the AU needs to ensure that troop-contributing states have conducted an appropriate and adequate review process to ensure persons guilty of serious criminal offences are not deployed. Moreover, there has to be an official process for monitoring the implementation of this, and a commitment to this set out in MOUs and SOFAs, as applicable. Moreover, any vetting process must be conducted across the spectrum of the categories of personnel deployed to peace operations, including senior mission leadership. There is anecdotal evidence that sometimes deployment to peace operations, where individuals often earn far higher than average home salaries, is perceived as an award for national military performance and regime loyalty. This means that not always the right people may be deployed. According to the Washington Post, for instance, '[i]n Burundi, a lieutenant makes about $\$ 500$ per year but can earn more than $\$ 12,000$ as a U.N. peacekeeper, according to interviews with eight former Burundian soldiers.'227

Pursuant to the HRDDP there is a requirement for pre-deployment risk assessments, screening and certification, enabling possible early identification of problem partnerships with non-UN security forces and/or individuals within these forces. ${ }^{228}$ With respect to Somalia, Legal Action Worldwide notes that such risk assessments should have fell within the purview of UNSOM and

\footnotetext{
225 SC Res 2127, UN SCOR, $7072^{\text {nd }} \mathrm{mtg}$, UN Doc S/RES/2127 (5 December 2013) [34].

226 Report of the Secretary-General on options for authorization and support for African Union peace support operations, UN SCOR, UN Doc S/2017/454 (26 May 2017) [45].

227 Sieff, above $\mathrm{n} 39$.

228 HRDDP, UN GAOR, UN SCOR, $67^{\text {th }}$ sess, UN Doc A/67/775-S/2013/110 (5 March 2013) Annex, Human Rights Due Diligence Policy on United Nations Support to Non-United Nations Security Forces.
} 
UNDP, but that UNSOM was not mandated with this responsibility until 2013, when support has already been provided to AMISOM and, indeed, the local SNA. ${ }^{229}$ Overall responsibility, however, for the operationalization of the HRDDP with respect to Somalia falls to the UN SRSG, who is responsible for informing those supported by the $\mathrm{UN}$, of compliance measures and any decisions regarding suspension of support for AMISOM and the local SNA, in consultation with UN HQ. ${ }^{230}$ As noted, a joint AU-UN Working Group on the implementation of the HRDDP with respect to AMISOM has been established, adopting a cooperative approach, but decisions on whether compliance measures pursuant to the HRDDP rightly remain with the UN. Notably, the HRDDP applies to situations where the UN actually supports, not merely authorizes military operations by non-UN security forces. This is not to state that, as a matter of best practice, regional and other military operations should not adopt similar due diligence procedures.

In May 2014 HRJS was mandated to prepare a report on allegations of human rights violations by MISCA troops so as to assess their re-deployability under a MINUSCA hat, by implication involving a re-hatting screening process. The CAR Panel report noted that it was advised that the HRDDP is not in any case consistently applied. In the context of AU MISCA in CAR, in the process of rapid re-hatting of MISCA troops to serve under the umbrella of the UN MINUSCA operation, the due diligence policy process reportedly was not effectively implemented. Despite evidence of egregious allegations of SEA reported in the media by some MISCA contingent personnel, a decision was made by the DPKo to integrate these personnel into MINUSCA. As noted in one UN report:

Challenges also arose in both countries with regard to the implementation of the United Nations human rights screening policy, owing to concerns about the human rights record of some contingents to be rehatted, including contingents belonging to national forces listed in the annexes of my annual report on children and armed conflict. ... As far as AFISMA and MISCA were concerned, the application of the human rights due diligence policy on United Nations support to non-United Nations security forces revealed several factors and risks that the Organization was compelled to take into consideration ahead of the rehatting process in the Central African Republic. Those concerns were only partially addressed

229 Legal Action Worldwide, above n 212, pp. 4, 7.

230 Letter dated 7 October 2015 from the Secretary-General addressed to the President of the Security Council, un Doc s/2015/762 (7 October 2015) [35]. 
by putting in place mitigation measures, including training and additional proactive screening of MISCA contingents in the case of the Central African Republic. In future, timely coordination on and implementation of the human rights screening policy at the earliest stages of the African Union-United Nations transition planning would enhance compliance with human rights standards. ${ }^{231}$

Indeed, there are reports that the AU did, not properly recruit some of these MISCA troops. ${ }^{232}$ This was likely due to a dire need by the UN to deploy troops to a highly volatile conflict-affected environment, with Western states continuing to deploy in dismally low numbers. As stipulated by a UN peacekeeping official in New York: 'It's so hard to generate troops to go to CAR that we can't afford to lose the Burundians. ${ }^{233}$ The UN reported in December 2016 that there is evidence that 25 Burundian peacekeepers deployed to Kemo, CAR, over the past two years, sexually abused civilians. ${ }^{234}$ Of course this is not limited to $\mathrm{Bu}-$ rundians, but also other nationalities. ${ }^{235}$ As the CAR Panel noted, this 'may be symptomatic of a broader problem of tolerance of sexual violence by international troops. ${ }^{236}$ The reality is that there are also drastic security implications of mass repatriation or blocking deployments from states whose armed forces and/or police may have been involved in past human rights abuses. That stated, this is not any argument against proper screening and vetting, as morality, ethics, policy and international laws require such. Indeed violations that were alleged against MISCA troops were not, according to the CAR Panel investigation, followed up on, at very least at the time of its 2016 report. The CAR Panel recommends broader application of procedures contained in the HRDDP to

231 Letter dated 2 January 2015 from the Secretary-General addressed to the President of the Security Council, un Doc s/2015/3 (5 January 2013) p. 6.

232 See, Carayannis and Fowlis, above n 34, pp. 228-229; CAR Panel Report, above n 2, p. 77.

233 Kevin Sieff, 'U.N. discovers that some peacekeepers have disturbing pasts', Washington Post (online), 26 December 2016 <https:/www.washingtonpost.com/world/africa/they -served-an-abusive-government-the-un-made-them-peacekeepers-anyway/2016/12/23/ o5coa5ad-108f-46b9-b6f7-5f2303f6cdfe_story.html?utm_term=.c2865126561f .

234 'Central African Republic: $U N$ completes investigations into allegations of sexual abuse by peacekeepers', United Nations New Centre (online), 5 December $2016<$ http://www .un.org/apps/news/story.asp?NewsID=55722\#.WdQuoluCypp>.

235 Kim Willsher and Sandra Laville, 'France Launches Criminal Inquiry into Alleged Sex Abuse by Peacekeepers', The Guardian (online), 7 May 2015 <http://www.theguardian .com/world/2015/may/o7/france-criminal-inquiry-alleged-sex-abuse-french-soldiers -un-central-african-republic $>$.

236 CAR Panel Report, above n 2, p. 74. 
peacekeepers serving on operations that do not receive UN support of the type set out in the Policy. ${ }^{237}$ The difficulties, however, with this recommendation is the need for state and regional or organizational cooperation, buy in, and UN capacity and resources. Capacity of the UN to deliver at this level is limited. However, as a matter of best practice, these organizations should develop parallel policies and effective implementation mechanisms. The UN could monitor these, at least on an audit type basis.

UN Commanders should be required to certify that they are not aware of any pending or past sexual violence offences by troops under their command, and report any allegations arising. ${ }^{238}$ The OHCHR Human Rights Database should include tracked incidents of sexual violence, including with respect to peacekeepers. The CAR Panel similarly recommends that troop-contributing states be required to screen troops, in line with the due diligence policy. ${ }^{239}$

The Un Multidimensional Integrated Mission in Mali ('MINUSMA') was established via UN SC Res 2100 (2013) on 25 April 2013 to deploy with the support of French troops and in cooperation with Malian defence and security forces. This involved a transfer of authority from the African-led International Support Mission in Mali ('AFISMA'), and effectively involved a re-hatting of most of the AU forces deployed under AFISMA. ${ }^{240}$ In so doing, it requested 'MINUSMA take fully into account the need to protect civilians and mitigate risk to civilians, including, in particular, women, children and displaced persons and civilian objects in the performance of its mandate ... where undertaken jointly with the Malian Defence and Security Forces, in strict compliance with the Human Rights Due Diligence Policy.'241

It is clear that there will be increased partnerships between the UN and regional bodies such as the AU and other such bodies in future peacekeeping, resulting in some scenarios arguably in a de facto outsourcing of peacekeeping. In 2016, a Joint UN-AU Framework for and Enhanced Partnership in Peace and Security was jointly drawn up by the UNOAU and AU's Peace and Security Department. While this is an important and strategic development with respect

\footnotetext{
237 Ibid., p. 93.

238 Ibid.

239 Ibid., p. 94.

240 'Afisma Transfers its Authority to MINUSMA', African Union, 1 July $2013<$ http://www .peaceau.org/en/article/afisma-transfers-its-authority-to-minusma >; See also, MINUSMA, <http://www.un.org/en/peacekeeping/missions/minusma/background.shtml>; Statement by Mr. Hervé Ladsous, Under-Secretary-General for Peacekeeping Operations, UN SCOR, $88^{\text {th }}$ sess, $6985^{\text {th }}$ mtg, UN Doc S/PV.6985 (25 June 2013) p. 5.

241 SC Res. 2100, 25 April 2013 [26] cited in Labbé and Boutellis, above n 210, p. 556.
} 
to the maintenance of international peace and security, implementation does give rise to concerns with respect to vetting, HRDDP implementation, regulatory frameworks, re-hatting issues, SEA accountability and prevention. The UN SG in his report 'The Future of UN Peace Operations: Report of the Secretary-General on the Recommendation of the High Level Independent Panel on Peace Operations', stresses that due regard will be given to providing support to the $\mathrm{AU}$ to better ensure that $\mathrm{AU}$ forces adhere to human rights, humanitarian law, and refugee law, in line with the UN's HRDDP. The SG has indicated that this will include 'pre-deployment training, monitoring and oversight mechanisms, and screening of personnel. ${ }^{242}$ Notably, the UN intends to establish operation transition benchmarks, in cooperation with the AU, to ensure smoother transitions from AU to UN missions. The SG has stipulated that:

It is incumbent ... to institutionalize consultative processes and, where appropriate, joint mechanisms. We have agreed to develop, by early 2016, a shared vision for benchmarks to guide transitions from African Union to United Nations operations, drawing on lessons from the Central African Republic, Mali and Somalia. We have also agreed to initiate joint work on standardizing the process of re-hatting uniformed personnel from African Union to United Nations operations, which will address, inter alia, training, equipment, sustainment and performance standards, conduct and accountability, and logistics support requirements. ${ }^{243}$

Focus will need to be placed vetting, screening, human rights and IHL violations, but also specifically SGBV, including exploitative sexual interactions with beneficiaries of assistance. Such transitions would be made easier if the AU were to implement appropriate standards and regulatory frameworks with its own structures, possibly reflecting those emerging in the last year at UN level. Moreover, the UN has recognized the need for it to support the AU in developing the AU's Conduct and Discipline Framework, and the strength of

242 See, e.g., Report of the High-level Independent Panel on Peace Operations on uniting our strengths for peace: politics, partnership and people, UN GAOR, UN SCOR, $70^{\text {th }}$ sess, UN Doc A/70/95, S/2015/446 (17 June 2015) p. 28; UN GAOR, UN SCOR, $70^{\text {th }}$, sess, Agenda Items 56 , 57 and 123, A/70/357-S/2015/682, (2 September 2015) [50].

243 UN GAOR, UN SCOR, $70^{\text {th }}$, sess, Agenda Items 56,57 and 123, A/70/357-S/2015/682, (2 September 2015) pp. 28, 29 [51]; See, e.g., Report of the High-level Independent Panel on Peace Operations on uniting our strengths for peace: politics, partnership and people, UN GAOR, UN SCOR, $70^{\text {th }}$ sess, UN Doc A/70/95, S/2015/446 (17 June 2015) p. 22. 
its capacity to do so, drawing on its own experiences with peace operations. ${ }^{244}$ In a 2017 report wherein it stated that:

There is also a need for a joint agreement between the United Nations and the African Union which describes the level, types and extent of support that would be expected from the United Nations in the implementation of the African Union's conduct and discipline framework, while ensuring that responsibility for addressing violations such as sexual exploitation and abuse remain with those directly accountable. ${ }^{245}$

It has also noted the need for UN appointments to ensure AU compliance with HRDDP, including the carrying out of risk assessments and monitoring. ${ }^{246}$ In turn the AU Commission Chairperson to the Peace and Security Council and the Security Council will need to report on compliance and accountability in line with standards of conduct applicable to military, civilian and police personnel, and IHL and IHRL. The UN has also stressed the need for AU transparency regarding its processes for ensuring adhere to these standards, ${ }^{247}$ which to date have been lacking. The UN has already worked with the AU on various missions to develop core documents to better regulate its operations, for instance in the case AFISMA in Mali, where the UN provides assistance in the development of 'operational directives, guidelines for the protection of civilians, rules of engagement and a code of conduct'. 248 SC Res 2320 (2016) called on the AU to 'provide an update on revised benchmarks and timelines for the implementation of the outstanding elements' of its human rights and conduct and discipline frameworks. ${ }^{249}$

The UN SG has requested states to ensure that those they deploy or re-hat meet UN standards. Moreover, in line with the HRDDP, the SG has called on states to provide information to inform its risk assessments pursuant to the

244 Report of the Secretary-General on options for authorization and support for African Union peace support operations, UN SCOR, UN Doc S/2017/454 (26 May 2017) [53]-[54], [70].

245 Ibid [59]; SC Res 2320, UN SCOR, 7816 ${ }^{\text {th }} \mathrm{mtg}$, Un Doc S/RES/2320 (18 November 2016).

246 Report of the Secretary-General on options for authorization and support for African Union peace support operations, UN SCOR, UN Doc S/2017/454 (26 May 2017).

247 Ibid., [23]-[24].

248 Statement by the Under-Secretary General for Political Affairs, UN SCOR, $6944^{\text {th }} \mathrm{mtg}, 68^{\text {th }}$ sess, Un Doc S/PV.6944 (3 April 2013) 4; Report of the Secretary-General on the situation in Mali, Un SCOR, Un Doc S/2013/189 (26 March 2013) p. 9 [47].

249 Report of the Secretary-General on options for authorization and support for African Union peace support operations, UN SCOR, UN Doc S/2017/454 (26 May 2017) [50]. 
Policy. ${ }^{250}$ Repeated appearance of a state's troops on the SG's reports on Children and Armed Conflict and on Conflict-Related Sexual Violence will cease to be accepted for deployment to UN operations. ${ }^{251}$ This should also be a standard applied with respect to support of non-UN forces, including the AU. Whole contingents from particular states whose troops have repeatedly been involved in SEA have been repatriated home in recent years. For instance, as recently as 6 June 2017, a confidential memo was released by the Code Blue Campaign, with respect to the UN's operation in the DRC, in which the MINUSCA Force Commander called for the repatriation of hundreds of UN troops from the Republic of the Congo based in Bereberati, due to rampant sexual abuse, fuelling of trafficking and poor discipline. Indeed 120 Congolese troops were repatriated in 2016 in relation to SEA. 252 This was despite protests of the Congolese government and was done to implement the HHRDP. ${ }^{253}$ However, the occurrence of abuse might also be linked to inadequacies in vetting in the re-hatting of these troops in the first instance. A confidential leaked report on the Congolese contingent noted lack of adequately secured camp parameters, making access by locals easy. Moreover, troops' living conditions were generally poor and their camps inadequately secured. No canteen existed for troops to purchase personal items, resulting in them going to local markets. There was also reportedly lack of communication facilities; no kitchen for cooking; food is often distributed on an individual basis, and left overs not properly dealt with; the water hole is/was $500 \mathrm{~m}$ from the camp. ${ }^{254}$ Amongst recommendations

250 See, e.g., Report of the High-level Independent Panel on Peace Operations on uniting our strengths for peace: politics, partnership and people, UN GAOR, UN SCOR, $70^{\text {th }}$ sess, UN Doc A/70/95, s/2015/446 (17 June 2015) p. $5^{2}$.

251 See, e.g., Conflict-related sexual violence: Report of the Secretary-General, UN SCOR, UN Doc s/2016/361 (20 April 2016).

252 Leaked memo, MINUSCA Force Commander to DPKO Military Advisor for Peacekeeping Operations, 12 May 2017, p. 8 <https://statici.squarespace.com/static/514a0127e 4bo4d 7440 e8045d/t/593704c246c3c49oc3eeob24/1496777924587/CAR+memo.pdf > and 14-16 March <https://static1.squarespace.com/static/514a0127e4bo4d $7440 \mathrm{e} 8045 \mathrm{~d} / \mathrm{t} / 593704 \mathrm{a} 2579 \mathrm{fb} 3$ 7a23567889/1496777906180/MINUSCA+ORA.pdf >; See also, Code Blue website <http:// www.codebluecampaign.com/press-releases/2017/6/6>.

253 Gerrit Kurtz, With Courage and Coherence: The Human Rights Up Front Initiative of the United Nations, Policy Paper (Global Public Policy Institute, July 2015) p. 24.

254 Leaked memo, MINUSCA Force Commander to DPKO Military Advisor for Peacekeeping Operations, 12 May 2017, pp. 8-15 <https://static1.squarespace.com/static/514ao127 e4bo4d7440e8045d/t/593704c246c3c49oc3eeob24/1496777924587/CAR+memo.pdf> and 14-16 March <https://static1.squarespace.com/static/514a0127e4bo4d 7440e8045d/t/5937o 4a2579fb37a23567889/149677790618o/MINUSCA+ORA.pdf >; See also, Code Blue website $<$ http://www.codebluecampaign.com/press-releases/2017/6/6>. 
made for improvement of the functioning of the Congolese troops was: 'management and destruction of leftover food'; control of 'unnecessary movement of troops around the camp without proper dress code'; boring of a well in camp so that troops do not need to leave to camp to collect water; and to '[c]ontinue to remind troops about compliance with the rules of engagement and discipline.'255 The report does note appropriate levels of training ('level 4') on SEA had been delivered, ${ }^{256}$ yet clearly this training has not been adhered to by a high number of contingent personnel.

The UN has stressed, that its support of the AU will be contingent on:

[c]onformity with United Nations rules and regulations; and strict compliance with the human rights due diligence policy and standards of conduct. These arrangements would be set out in a memorandum of understanding between the United Nations and the African Union and in line with United Nations standards and practices. ${ }^{257}$

\section{Conclusion}

Increasing reliance on regional peacekeeping operations in the maintenance of international peace and security is likely to become more prevalent for a variety of reasons. There is also a likelihood of increased sequential deployments and re-hatting of peacekeepers. Indeed, with respect to AM Isom, for example, in the long-term there are indications of support from members of the UN SC that AM ISOM personnel be re-hatted under the umbrella of a UN operation. The short to medium-term approach has been for the $\mathrm{EU}$ and UN to provide support to the AU peace operation. ${ }^{258}$ With respect to $\mathrm{AU}$ operations and UN support for these, this is still a relatively recent phenomenon, and the AU is still building its institutional, policy and regulatory frameworks, but developments have be sparse and not concrete. Therefore, this is an opportune moment to seriously reflect on the UN's experiences in relation to building response and

255 Leaked confidential memo: MINUSCA FHQ, In Mission Operational Readiness Assessment of COGBAT-3, 14-16 March 2017, p. 62, available under 'assessment' link at: Code Blue webpage $<$ http://www.codebluecampaign.com/press-releases/2017/6/6>.

256 Ibid.

257 Report of the Secretary-General on options for authorization and support for African Union peace support operations, UN SCOR, UN Doc S/2017/454 (26 May 2017) [46].

258 Global Peace Operations Review: Annual Compilation 2016 (Center on International Cooperation, 2017) p. 232. 
prevention mechanisms in dealing with SEA by UN peacekeepers. Risks of SEA, at least in UN operations, are associated with the level of volatility of operational environments. According to a 2017 UN SG report, risks of SEA increase 'in single-nationality deployments to remote locations; and among personnel, forces or partners that have no prior experience with United Nations field operations. ${ }^{259}$ As noted, regional operations frequently deploy to more volatile situations than the UN, where rule of law is weak or virtually absent. An unavoidable reality is that peacekeepers are engaged in contexts where sexual and gender based violence is one of the dire faces of armed-conflict and its aftermath. Peacekeepers are key to stabilization efforts, local institutional capacity and security and legal sector reform. Addressing SGBV by peacekeepers themselves is an essential first step if they are to effectively address SGBV in these broader contexts. ${ }^{260}$

It appears rational, given UN obligations under the HRRDP but also given the wealth of experience the UN has unfortunately gained in dealing with SEA by UN peacekeepers, that the AU draw on UN lessons-learned in developing its SEA regulatory and policy frameworks. Moreover, it would be nonsensical for the AU to try to re-invent the wheel. This is not to state that UN practice in this area does not still suffer from significant lacunas and flaws, the scope of which and suggested ways forward are beyond the remit of this article. ${ }^{261}$ These issues also have to be dealt with by AU with respect to its peacekeeping personnel, rather than attempting to replicate in a system, created over 20 years, that simply did not sufficiently work in terms of countering impunity and provide remedial measures for victims of SEA. Nevertheless, drawing on the UN's experience does provide a starting platform in establishing best practice in this area. Moreover, establishing a proper regulatory system to deal with and prosecute perpetrators can only send a strong message to local communities that abuse will not be tolerated, regardless of who you are and the power you wield.

259 Special Measures for Protection from Sexual Exploitation and Abuse: A New Approach Report of the Secretary-General, UN Doc A/71/818 (28 February 2017) [11].

260 See, e.g., Róisín Burke, 'Troop-discipline, the Rule of Law and Mission Operational Effectiveness in Conflict-Affected States', in Morten Bergsmo and Tianying Song (eds), Military Self-Interest in Accountability for Core International Crimes (Brussels: Torkel Opsahl Academic EPublisher, 2015) pp. 359-399.

261 See, Burke, Sexual Exploitation and Abuse: Moving Beyond, above n 1; William Durch, Katherine Andrews and Madeline England, with Matthew Weed, Improving Accountability Criminal Accountability in United Nations Peace Operations, Report from the Project on Rule of Law in Post-Conflict Settings, Stimson Centre Report No 65(1) (June 2009); Burke, 'Central African Republic Peacekeeper Sexual Crimes, Institutional Failings', above n 3. 
This is particularly important in the realm of standard setting and capacitybuilding of national policing and armed forces. ${ }^{262}$

The AU's Common African position on the UN Review of Peace Operations, outlines a series of actions to be taken for better cooperation and partnership between the $\mathrm{UN}$ and $\mathrm{AU}$ in conducting peace operations. It recognizes that this includes joint development of best practices and lessons learned. ${ }^{263}$ The need to jointly deal with the negative impacts of peacekeeping, including SEA, is specifically identified, in addition to corruption and other forms of misconduct. The AU further recognizes the need to develop a joint database to ensure those found to have perpetrated prior incidents of misconduct are not redeployed to UN or AU peace operations. Moreover, it stresses the need for accountability and that its zero-tolerance polices are strictly implemented. Interestingly, the AU specifically states: 'in the case of sexual violence and abuse perpetrated by peacekeepers, the mandating authority (e.g. The UN or the AU) should exercise accountability and justice, rather than the troop-contributing states, as has been the case to date. ${ }^{264}$ As it stands the AU and the Un have no capacity to exercise criminal jurisdiction over troops deployed, their capacity to take action, as noted, is limited largely to the administrative measures of repatriation and refusal to re-deploy implicated personnel. Criminal investigation and prosecution, and indeed any disciplinary measures, will likely remain within the purview of troop-contributing states, and possibly police-contributing states. This is on account of privileges and immunities granted to peacekeeping personnel. There, however, been suggestions with respect to SEA by UN peacekeepers to establish some form of a hybrid or tri-hybrid court and investigative mechanisms, exploration of which is beyond the scope of this paper, but which has been discussed by a number of academic and legal experts. ${ }^{265}$ This discussion is also relevant to $\mathrm{AU}$ peacekeepers, which operate in many respects under similar legal difficulties. State buy-in to such an institution, particularly with respect to their armed forces, is unlikely.

262 Burke, 'Troop-discipline, the Rule of Law and Mission Operational Effectiveness in Conflict-Affected States', above $\mathrm{n} 260$.

263 Common African Position on the AU Review of Peace Operations, AU Peace and Security Council, 202 ${ }^{\text {nd }} \mathrm{mtg}$, AU Doc PSC/PR/2(DII) (29 April 2015) pp. 5-6 [12].

264 Common African Position on the AU Review of Peace Operations, AU Peace and Security Council, 202 ${ }^{\text {nd }} \mathrm{mtg}$, AU Doc PSC/PR/2(DII) (29 April 2015) p. 14 [12][vii].

265 See, e.g., Burke, Sexual Exploitation and Abuse: Moving Beyond, above n 1; Ensuring the Accountability of United Nations Staff and Experts on Mission with Respect to Criminal Acts Committed in Peacekeeping Operations - Report of the Group of Legal Experts, UN GAOR, $60^{\text {th }}$ sess, Agenda Item 32, UN Doc A/6o/98o (16 August 2006); Durch, Andrews and England, with Weed, above n 260 . 
The AU Commission paper notes the established practice of re-hatting of AU mission troops and police to UN operations. In this respect, it highlights the need to establish a 'best practice working group on transitions' to learn from the experiences in such transitions from Mali and CAR, with the aim of drawing up guidelines and a joint AU-UN policy on these operation transitions. ${ }^{266}$

Failure to ensure appropriately vetted troops in the re-hatting process, in addition to lending support to regional organizations such as the $\mathrm{AU}$, where adequate procedures and a regulatory framework are not in place for dealing with SEA and, indeed, other crimes, could lead to implications for state or international organization responsibility for the AU, and plausibly the UN. Addressing this will ease the process of re-hatting and the transition from one type of operation to another. SEA is only an illustrative aspect of far greater problems and consequential impacts of the HRDDP implementation, supports, and re-hatting processes. ${ }^{267}$

A challenge for the AU going forward will be translate its commitments on paper to concrete implementation strategies and frameworks. This has not yet been achieved. Transparency of such frameworks is essential. The victims, and their representatives, need to know what body is responsible for the intake of complaints and how, and by whom, they will be supported. The procedure by which their complaint will be processed and dealt with, and what body is responsible for this, must be clear across all AU operations. These procedures are not transparent in AMISOM, where complaints of SEA were widely publicized, not to mind other AU peace operations. This suggests this framework simply does not yet exist, at least at a centralized level. AU responses to this issue should be forward-thinking if it desires its peace operations to be seen as adhering to international standards and best practices, rather than reactionary and $a d$ hoc. To be fair, the UN itself has responded poorly to SEA by its peacekeepers, but the AU has the advantage of developing strategies and procedures off the back of lessons learned from UN operations. Moreover, the UN's support for AU operations should be contingent on the building such frameworks to deal with SEA. The UN should work in partnership with the AU in doing so, particularly in light of the UN's HRDDP but also in light of obvious AU resource constraints. The $\mathrm{AU}$, however, cannot use resource constraints as an excuse for not ensuring a better response to SEA. In the continued institutionalization of cooperation and partnership with the $\mathrm{AU}$ in peace operations, the

\footnotetext{
266 Common African Position on the AU Review of Peace Operations, AU Peace and Security Council, 202 ${ }^{\text {nd }} \mathrm{mtg}$, AU Doc PSC/PR/2(DII) (29 April 2015) p. 6 [12].

267 Boisson de Chazournes, above n 13, pp. 142-254.
} 
UN SG intends to 'reflect expectations of accountability measures in cooperation agreements with the African Union'. ${ }^{268}$

There have been references to draft SEA, Whistleblower and Conduct and Discipline frameworks, policies and procedures being developed at AU level. These should draw on current regulatory frameworks being developed by the UN rather than past. These need to be finalized and released by the AU. A Misconduct, IHL, IHRL, and other serious crimes (including SEA) tracking database need to be fully established, and linked to that of the UN. A Victim Support Strategy, trust fund and framework, akin to that of the UN, needs to be put in place by the AU. This should take into account the need for medical, legal, and socio-economic supports, in addition to dealing with paternity claims in addressing the issue of peacekeeper babies. Staged payments of peacekeepers while on deployment should be considered. With respect to investigations, there is a need at both AU and UN level to engage 'expertise in forensic analysis, sexual crimes and the special needs of children' in investigative process. ${ }^{269}$ There is a need to put in place SEA witness and victim protection measures. ${ }^{270}$ Joint investigations using external independent experts, drawing on a permanent capacity, is recommended to better ensure accountability. The UN SG has recommended with respect to UN peacekeepers that states '[a]gree to in situ courts martial or permit their live-streaming to enable victims' access to criminal proceedings'; and that states '[a]gree to obtain DNA, on a voluntary basis, from all deployed personnel for purposes of exoneration or conviction of individuals accused of sexual exploitation and abuse. ${ }^{271}$ These recommendations should apply also to states contributing to AU operations. A timeframe for responding to SEA allegations should be institutionalized by the AU to ensure evidence is not lost.

Global/joint trainings on gender, local cultural contexts and SEA, and certification for such are necessary. These trainings should also be inserted in

268 Special measures for protection from sexual exploitation and sexual abuse Report of the Secretary-General, UN GAOR, $79^{\text {th }}$ sess, Agenda Item 139, UN Doc A/70/729 (16 February 2016) [82].

269 Special Measures for Protection from Sexual Exploitation and Abuse: A New Approach Report of the Secretary-General, UN Doc A/71/818 (28 February 2017) [48].

270 Ibid.

271 Special measures for protection from sexual exploitation and sexual abuse: Report of the Secretary-General, UN GAOR, $69^{\text {th }}$ sess, A/69/779 (2015) [6o]; Special measures for protection from sexual exploitation and sexual abuse Report of the Secretary-General, UN GAOR, $79^{\text {th }}$ sess, Agenda Item 139, UN Doc A/70/729 (16 February 2016) [31]; Special Measures for Protection from Sexual Exploitation and Abuse: A New Approach Report of the SecretaryGeneral, Un Doc A/71/818 (28 February 2017) p. 15 . 
national and regional curricula. Training is particularly pertinent in environments where there exist significant cultural, legal, policy and institutional variances.

The AU should work in partnership with the UN and find a way to align policy documents, regulatory framework and procedures, which may also be of relevance to monitoring mechanisms, risk assessments, and mitigation measures under the HRDDP. UN GA Res 286 specifically requests the SG 'to include in future reports information on allegations of sexual exploitation and abuse by non-United Nations forces operating under a Security Council mandate.'272 Irrespective of the AUs regulatory framework, the AU, troop and police contributing states, and their forces, nevertheless, to varying degrees are bound to adhere to a broader array of human rights and IHL instruments, which provide some protections against SGBV. A shift in attitudes is required by all peacekeeping actors wherein the past, too often, organizations have sought to avoid reputational impacts by sweeping the problem of SEA under the carpet instead of developing best practice and the sharing of such amongst peacekeeping organizations.

272 Special Measures for Protection from Sexual Exploitation and Abuse: A New Approach Report of the Secretary-General, UN Doc A/71/818 (28 February 2017) [13]. 